\title{
A simple model to evaluate ice melt over the ablation area of glaciers in the Central Karakoram National Park, Pakistan
}

\author{
U. MINORA, ${ }^{1,2}$ A. SENESE, ${ }^{1}$ D. BOCCHIOLA ${ }^{2,3}$ A. SONCINI, ${ }^{2}$ C. D'AGATA, ${ }^{1,3}$ \\ R. AMBROSINI, ${ }^{4}$ C. MAYER, ${ }^{3,5}$ A. LAMBRECHT, ${ }^{5}$ E. VUILLERMOZ, ${ }^{3}$ C. SMIRAGLIA,,${ }^{1,3}$ \\ G. DIOLAIUTI ${ }^{1,3}$
}

\author{
1 'A. Desio' Department of Earth Sciences, Università degli Studi di Milano, Milan, Italy \\ ${ }^{2}$ Department of Civil and Environmental Engineering, Politecnico di Milano, Milan, Italy \\ ${ }^{3}$ Ev-K2-CNR, Bergamo, Italy \\ ${ }^{4}$ Department of Biotechnology and Biosciences, Università degli Studi di Milano Bicocca, Milan, Italy \\ ${ }^{5}$ Bavarian Academy of Sciences and Humanities, Munich, Germany \\ Correspondence: A. Senese <antonella.senese@unimi.it>
}

\begin{abstract}
This study provides an estimate of fresh water derived from ice melt for the ablation areas of glaciers in the Central Karakoram National Park (CKNP), Pakistan. In the CKNP there are $\sim 700$ glaciers, covering $\sim 4600 \mathrm{~km}^{2}$, with widespread debris cover $\left(518 \mathrm{~km}^{2}\right)$. To assess meltwater volume we applied a distributed model able to describe both debris-covered and debris-free ice ablation. The model was calibrated using data collected in the field in the CKNP area and validated by comparison with ablation data collected in the field, independent of the data used in building the model. During 23 July-9 August 2011, the mean model-estimated ablation in the CKNP was $0.024 \mathrm{~m} \mathrm{w.e.}^{-1}$ in debriscovered areas and $0.037 \mathrm{mw} . \mathrm{m}^{-1}$ in debris-free areas. We found a mean error of $+0.01 \mathrm{mw}$.e. (corresponding to $2 \%$ ) and a root-mean-square error equal to $0.09 \mathrm{mw.e}$. (17\%). According to our model, the ablation areas of all the glaciers in the CKNP produced a water volume of $1.963 \mathrm{~km}^{3} \mathrm{during}$ the study period. Finally, we performed several sensitivity tests for assessing the impact of the input data variations.
\end{abstract}

KEYWORDS: debris-covered glaciers, glacier ablation phenomena, glacier modelling, remote sensing, surface melt

\section{INTRODUCTION}

The largest glacierized region outside the Arctic and the Antarctic is High Mountain Asia (HMA), which covers an area of $118200 \mathrm{~km}^{2}$ (Gardner and others, 2013). Changes in glacier extent and volume in this region are spatially heterogeneous and poorly known (Bolch and others, 2012). Indeed, recent studies revealed that most of the northwestern Himalaya have experienced less glacier shrinkage than the eastern parts of the same mountain range (Bhambri and Bolch, 2009; Bolch and others, 2012; Kääb and others, 2012). In the western and central Karakoram region, glaciers showed long-term irregular behavior with frequent advances, and possible slight mass gain in the last decade (Copland and others, 2011; Hewitt, 2011; Bolch and others, 2012; Gardelle and others, 2012, 2013; Kääb and others, 2012; Minora and others, 2013; Soncini and others, 2015). Gardelle and others' (2012, 2013) recent studies demonstrate how, in contrast to widespread global glacier retreat, glaciers in the Karakoram region as a whole have exhibited a general mass-balance stability (the so called 'Karakoram anomaly'; Hewitt, 2005, 2011). Advances of individual glaciers have also been reported in the Shyok valley (eastern Karakoram) during the last decade (Raina and Srivastva, 2008). These individual advances and mass gain episodes could be attributed to surging (Barrand and Murray, 2006; Hewitt, 2007; Copland and others, 2011; Quincey and others, 2011), temperature drops (Shekhar and others, 2010) and increased solid precipitation in the accumulation areas (Fowler and Archer,
2006; Bocchiola and Diolaiuti, 2013). The Karakoram glaciers are a strategic resource for Pakistan, because they provide fresh water for civil use, hydropower production and farming. The glacierized Karakoram is therefore a key area for studying the effects of ongoing climate change on present and future meltwater discharge.

This study focuses on the glacier ablation areas within the Central Karakoram National Park (CKNP), with the aim of assessing the magnitude and rate of ice ablation and evaluating the derived meltwater amount. For this purpose, we applied a distributed model able to describe ablation in debris-covered and debris-free conditions (Pellicciotti and others, 2005; Mihalcea and others, 2008a). Indeed, a significant portion of the glaciers in the CKNP is covered by a supraglacial debris layer, modulating the magnitude and rate of ice ablation (Nakawo and Young, 1981; Nakawo and Takahashi, 1982; Nicholson and Benn, 2006; Mihalcea and others, 2008a,b; Reid and Brock, 2010). This debris layer must therefore be accurately considered in distributed modeling of ice melt.

While quite a few energy- and mass-balance studies have been performed on debris-free glaciers, studies including debris-covered ice are not numerous. In the recent past, some authors have focused their attention on debris-covered ice only, and at single-point sites. For example, Nicholson and Benn (2006) presented a modified surface energybalance model to calculate melt beneath a debris layer from daily mean meteorological data on two European debriscovered glaciers (Ghiacciaio del Belvedere, Italy, and 


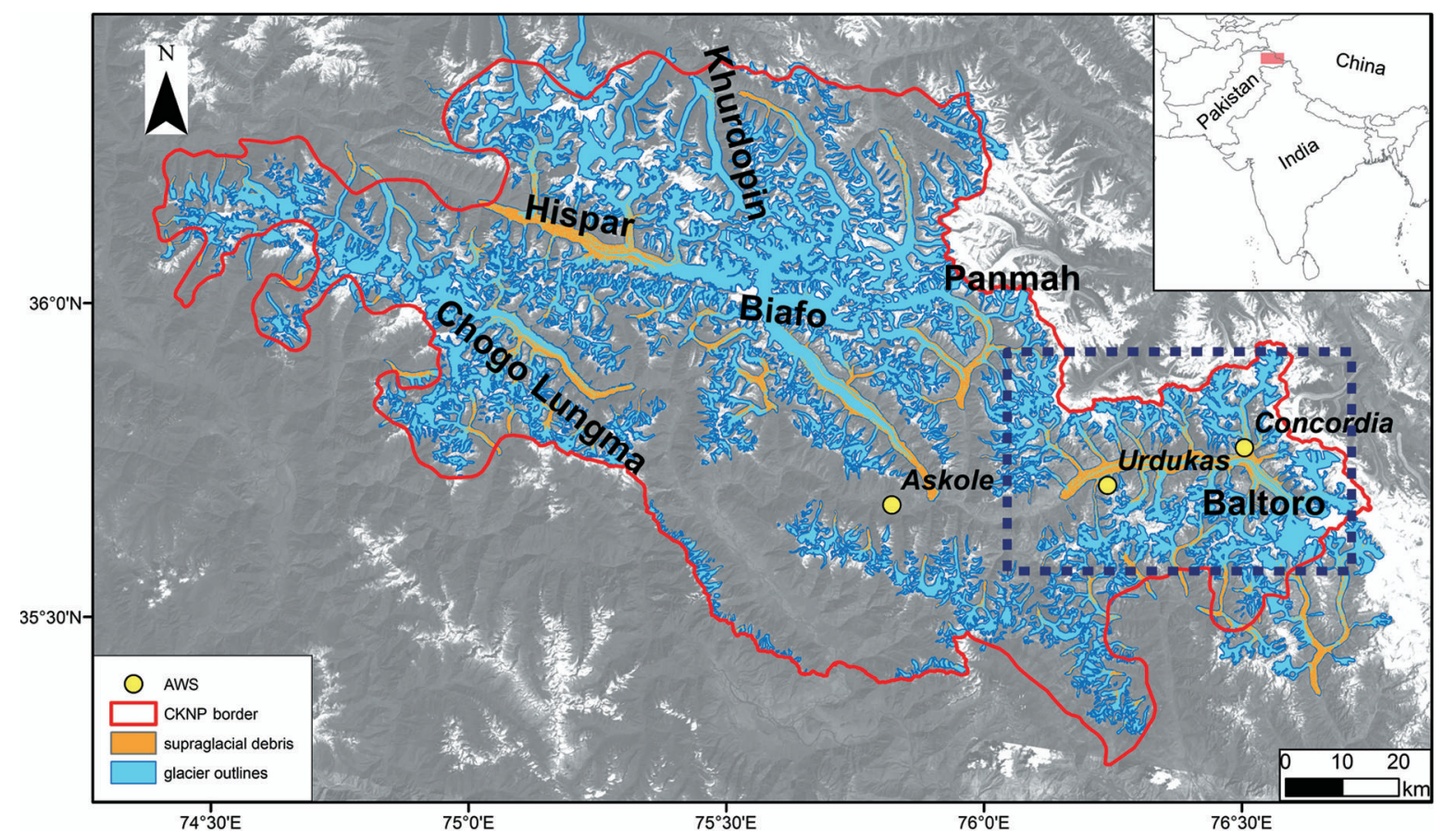

Fig. 1. Study area. The map shows the border of the Central Karakoram National Park (CKNP) in northern Pakistan (red line), the automatic weather stations at Askole, Urdukas and Concordia (yellow dots), the glacier boundaries (blue lines), and the glacier areas covered by supraglacial debris (orange). Names of the widest glaciers are shown, with the area of Baltoro glacier highlighted by a box with blue dashed line.

Larsbreen, Norway). Han and others (2006) proposed a simple model to estimate ice ablation under a thick debris layer by using surface temperature and debris thermal properties on Koxkar glacier, Tien Shan, China. During the last two decades, a few papers have focused on debriscovered glaciers in the Himalaya and Karakoram (e.g. Hewitt and others, 1989; Mattson and Gardner, 1989; Mattson and others, 1993; Young and Hewitt, 1993; Nakawo and Rana, 1999; Kayastha and others, 2000; Nakawo and others, 2000; Takeuchi and others, 2000; Lejeune and others, 2013). Some studies have used remotesensing data to analyze the spatial distribution of surface temperatures and calculate the energy available for melting (Nakawo and others, 1993; Rana and others, 1997; Nakawo and Rana, 1999). Unfortunately, these studies only provided melt data over small areas and short time spans. Mihalcea and others (2008a) modeled debris-covered ice ablation over the whole Baltoro glacier ablation area by applying a distributed approach, based on computation of the conductive heat flux through the debris layer and requiring information on debris thickness distribution derived from ASTER (Advanced Spaceborne Thermal Emission and Reflection Radiometer) thermal data. This approach has also been used by Zhang and others (2011) who applied it on Hailuogou glacier, southeastern Tibetan Plateau, and more recently by Fujita and Sakai (2014) on the Tsho Rolpa glacial lake-Trambau glacier basin in the Nepal Himalaya. Fyffe and others (2014) developed a melt model, which calculates sub-debris melt rates using an existing debris energybalance model (DEB-Model introduced by Reid and Brock, 2010) and melt rates for clean ice, snow and partially debriscovered ice using standard energy-balance equations. This approach is more exhaustive (but also more complex) than that of Mihalcea and others (2008a), though its application to a whole glacierized watershed or an entire glacier region is not simple, and requires input data featuring high spatial and temporal resolution, not always available in remote high-elevation glacier zones. Therefore, the results we present in this study were obtained for the entire CKNP debris-covered ice zone by applying the model developed by Mihalcea and others (2008b). Furthermore, we assessed the contribution of debris-free ice melt to fresh water from the whole CKNP ablation area. Modeling of debris-free ice melt has been extensively analyzed in the recent past, and several attempts have been made to apply the degree-day approach or simplified energy budget computations to large and representative glacierized catchments worldwide. Nevertheless, on large and remote glacierized catchments, only a few attempts to model debris-free ice melt coupled with approaches estimating debris-covered ice ablation are available (e.g. Soncini and others, 2015). In our study, we evaluate ice melt in debris-free conditions by applying an enhanced $T$-index model (following Pellicciotti and others, 2005), which also considers solar energy inputs in driving ice melt. This melt model was coupled with the debriscovered ice melt model, thus obtaining a suitable tool to be applied on large and remote glacierized areas featuring both debris-covered and debris-free ice conditions.

\section{STUDY SITE}

The CKNP is a protected area established in 2009 covering $12162 \mathrm{~km}^{2}$ in northeastern Pakistan, at the border with India and China (Fig. 1). The park protects major natural resources for the country, including $>700$ glaciers, with a total area of $4632 \mathrm{~km}^{2}$, corresponding to $\sim 30 \%$ of the overall glacier area of the Pakistani Karakoram (ICIMOD, 2013). Glaciers in the CKNP span a broad range of sizes, types (mountain glaciers, glacierets, hanging glaciers, compound-basin valley glaciers), and surface conditions (debris-free and debris-covered ice). In addition, the Karakoram is known to host several surge-type glaciers (Diolaiuti and others, 2003; 
Barrand and Murray, 2006; Hewitt, 2007, 2011; Kotlyakov and others, 2008; Gardelle and others, 2012), displaying cyclically short active phases involving rapid mass transfer from high to low elevations, and long quiescent phases of low mass fluxes. Copland and others (2011) reported 90 surge-type glaciers in the Karakoram mountains. In particular, in the 14 years after 1990, they found double the number of new surges (26) compared with those counted in the 14 years before (13 surges).

The ablation areas of many glaciers in the CKNP are heavily debris-covered, because of abundant rockfalls from steep walls, and intense avalanche activity (e.g. Bolch and others, 2012). Supraglacial debris covers $\sim 10 \%$ of the total glacier area in the Karakoram (Bolch and others, 2012).

Baltoro glacier is one of the largest debris-covered glaciers in the Karakoram Range, with a maximum length of $\sim 62 \mathrm{~km}$ and an area of $\sim 524 \mathrm{~km}^{2}$, including all connected tributaries (Mayer and others, 2006). The total drainage basin of Baltoro glacier is $\sim 1500 \mathrm{~km}^{2}$. It extends in the east-west direction on the south side of the Karakoram Range, lying in the region $35^{\circ} 35^{\prime}-35^{\circ} 56^{\prime} \mathrm{N}, 76^{\circ} 04^{\prime}-$ $76^{\circ} 46^{\prime} \mathrm{E}$. The Baltoro glacier elevation ranges between $3370 \mathrm{~m}$ a.s.I. and the K2 summit (8611 ma.s.I.). Supraglacial debris of diverse lithology (Desio and others, 1961) occurs below $5000 \mathrm{~m}$ a.s.l., and covers $\sim 38 \%$ of the glacier area. The grain size shows a large variability on the glacier, from sub-millimeter dust to boulders of a few meters diameter (Mayer and others, 2006), and this is typical of the whole Karakoram debris-covered area (Mihalcea and others, 2008a; Zhang and others, 2013). In the highest parts of Baltoro glacier, the debris occurs over medial moraines, then gradually spreads to a uniform cover across the entire surface, mantling most of the ablation zone. Near the terminus, the debris thickness may exceed $1 \mathrm{~m}$ (Mayer and others, 2006). Debris cover has been present on this glacier for at least the last century (historical data reported by Conway, 1894; De Filippi, 1912).

Because of its size and the proportion of area covered by supraglacial debris (38\% debris-covered and 62\% debrisfree), and its elevation (the equilibrium-line altitude (ELA) was reported to be at 5200 ma.s.l. by Mayer and others, 2006, and Bocchiola and others, 2011), Baltoro glacier can be considered paradigmatic of glacierized areas in the CKNP. It will therefore be our focus here for calibrating and validating the melt models.

In addition, permanent automatic weather stations (AWSs) operate on the glacier (at Urdukas, on a lateral moraine at $3926 \mathrm{~m}$ a.s.I., and Concordia, on the glacier melting surface at $4700 \mathrm{~m}$ a.s.I.), as well as in Askole (3029 m a.s.I.), the first village down-valley from Baltoro glacier (Fig. 1). These AWSs are part of the SHARE (Stations at High Altitude for Research on the Environment) network (an international project launched by the Ev-K2-CNR Chartered Association). These stations, managed with the support and agreement of the Pakistan Meteorological Department, provided input data for developing the melt models.

According to the Köppen-Geiger classification, this area falls in a cold desert region with a dry climate, little precipitation, a mean annual temperature lower than $18^{\circ} \mathrm{C}$, and a wide daily temperature range (this type of arid, desert and cold climate is identified with the symbol BWk; Peel and others, 2007). The Nanga Parbat massif forms a barrier to the northward movement of monsoon storms, which intrudes little in Karakoram. The hydrometeorological regime is barely influenced by monsoons, while a major contribution results from snow and ice melt. Precipitation is gathered in two main periods, summer (July-September) and winter (January-March), i.e. the seasons of the monsoons and the westerlies, the latter providing the dominant nourishment for glaciers. Some studies indicate that the total annual rainfall is $200-500 \mathrm{~mm}$, as generally derived from valley-based stations, less representative for the highest zones (Archer, 2003). Estimates from snow pits above $4000 \mathrm{~m}$ a.s.l. range from 1000 to $>3000 \mathrm{~mm}$ w.e. (Winiger and others, 2005). However, there is considerable uncertainty about the behavior of precipitation at high altitudes. Recent studies (e.g. Bocchiola and Diolaiuti, 2013; Minora and others, 2013) have highlighted climate and snowcover trends within this area in the period 1980-2009. Even if no significant changes of precipitation amounts have been detected, the number of rainy days appears to have increased. Regarding air temperature, the maxima have generally increased, while the minima appear to have decreased only during summer.

\section{METHODS}

Since snow depth data in the CKNP area are scant and spotty, our study focused on modeling ice melt only, neglecting snowmelt. Following previous studies (Mayer and others, 2006; Mihalcea and others, 2008a; Bocchiola and others, 2011; Soncini and others, 2015), we set the ELA at $5200 \mathrm{ma}$ a.s.l., and we then applied the model only to glacier areas below that level, i.e. in the ablation zone. According to this criterion, the ablation zones of glaciers cover $3138 \mathrm{~km}^{2}$, or $67.75 \%$ of the total glacierized area, in the CKNP. In addition, our analyses covered the period 23 July-9 August 2011, corresponding to the season when the largest glacier melt occurs during the year. The choice of limiting the application of the models to areas $<5200 \mathrm{~m}$ a.s.l. may lead to underestimation of the actual glacier melt, as melt can occur above this elevation threshold, however limited in this season. Indeed, Soncini and others (2015) analyzed the hydrological regimes of the Shigar river, covering $\sim 7000 \mathrm{~km}^{2}$ in the upper Karakoram, and nesting $\sim 2000 \mathrm{~km}^{2}$ of glaciers (including Baltoro, Biafo, Chogo Lungma), and found that snowmelt contribution was limited during our time frame (i.e. $<20 \%$ considering the entire basin and not only glacier areas).

We applied two distributed melt models, one for debriscovered and one for debris-free areas. Both models were calibrated using field data gathered during an expedition on Baltoro glacier performed during 2011 (see Table 2 further below).

To model the ice melting amount in the whole CKNP glacier ablation area, we considered the following input data:

1. The glacier boundaries: the CKNP glacier inventory was derived by Minora and others (2013), who applied remote-sensing investigations. More precisely, Landsat Thematic Mapper (TM) and Enhanced TM Plus (ETM+) scenes of 2010 were processed and analyzed (Table 1).

2. A digital elevation model (DEM) describing the CKNP area (derived from the Shuttle Radar Topography Mission, SRTM3).

3. A supraglacial debris cover map: a map describing the occurrence of supraglacial debris was obtained by 
Table 1. Source, acquisition date and code scene of each satellite image used for the assessment of debris thickness distribution. Site displayed by each image is also reported

\begin{tabular}{lccc}
\hline Source & Acquisition date & Code scene & Site \\
\hline Landsat & 10 Aug 2011 & LT51480352011222KHC00 & East part of CKNP mosaic \\
Landsat & 17 Aug 2011 & LT51490352011229KHC00 & West part of CKNP mosaic \\
Landsat & 14 Aug 2004 & LE71480352004227PFS01 & Baltoro glacier, used in this study for comparison with Mihalcea and others (2008a) \\
ASTER & 14 Aug 2004 & AST_08_00308142004054614 & Baltoro glacier, analyzed by Mihalcea and others (2008a) \\
\hline
\end{tabular}

applying a supervised maximum likelihood (SML) classification to a 2011 Landsat false-color composite image (i.e. 543 bands) (Table 1). This map allowed the separation of the debris-free and debris-covered zones of each glacier.

4. Meteorological input data: the daily mean air temperature $\left(T_{\text {a-Askole; }}{ }^{\circ} \mathrm{C}\right)$ and the daily mean incoming solar radiation $\left(\mathrm{SW}_{\text {in-Askole; }} \mathrm{W} \mathrm{m}^{-2}\right)$ were obtained from hourly data measured during summer 2011 by the permanent AWS installed at Askole (Fig. 1). We used $T_{\text {a-Askole }}$ and $\mathrm{SW}_{\text {in-Askole }}$ to evaluate ice melt over debris-free areas, by applying an enhanced $T$-index approach (Pellicciotti and others, 2005). SW in-Askole was also considered in the debris-covered ice melt model in order to estimate the surface debris temperature $\left(T_{\mathrm{S} \text {-point; }}{ }^{\circ} \mathrm{C}\right)$ driving the energy available at the debris-ice interface for ice melt.

5. Debris data: (a) a map describing the supraglacial debris thicknesses ( $\mathrm{DT}_{\text {point; }} \mathrm{m}$ ) was derived from Landsat TM thermal band imagery from August 2011 ( $T_{\mathrm{S} \text {-Landsat; }} \mathrm{K}$ ); (b) daily surface debris temperatures $\left(T_{\mathrm{S} \text {-point } ;}{ }^{\circ} \mathrm{C}\right)$ in each pixel of the $\mathrm{DT}_{\text {point }}$ map and for each day in our period were computed by considering both daily incoming solar radiation data $\left(\mathrm{SW}_{\text {in-point; }} \mathrm{W} \mathrm{m}^{-2}\right)$ and debris thickness values (DT point; $\mathrm{m}$ ); and (c) the debris effective thermal resistance $\left(\mathrm{DR}_{\text {point }} ; \mathrm{m}^{2}{ }^{\circ} \mathrm{CW}^{-1}\right)$ was evaluated from debris thickness values by applying an empirical relation developed by Mihalcea and others (2008a). The data in (a), (b) and (c) are the main inputs in the debriscovered ice melt model because they allowed estimation of the conductive heat flux through the debris layer and, consequently, of the ablation rate.

The total melting ( $М_{\text {Tот; }} \mathrm{m}$ w.e.) in both debris-covered and debris-free ice zones was estimated as

$$
M_{\text {TOT }}=\sum_{i=1}^{k}\left[\sum_{\text {point }=1}^{n}\left(M_{\text {DC-point }}\right)+\sum_{\text {point }=1}^{m}\left(M_{\text {DF-point }}\right)\right] \text {, }
$$

where $n$ and $m$ are the total number of pixels (each pixel is $30 \mathrm{~m} \times 30 \mathrm{~m}$ in size) of the digital image corresponding, respectively, to debris-covered and debris-free glacier areas, $k$ is the length of the study period (days) and $M_{\text {DC-point }}$ and $M_{\text {DF-point }}$ are the melting rates over debris-covered and debris-free areas, respectively. $M_{\text {DC-point }}$ and $M_{\text {DF-point }}$ are fully described in Sections 3.3 and 3.4 respectively. The distribution of the meteorological parameters is reported in Section 3.1 and the evaluation of debris features is discussed in Section 3.2.

\subsection{Distribution of the meteorological parameters}

The meteorological data obtained from the AWS at Askole were corrected applying an altitudinal gradient to obtain estimated meteorological data on the whole glacier ablation areas of the CKNP. In particular, the daily mean air temperature $\left(T_{\text {a-point }}{ }^{\circ} \mathrm{C}\right)$ was modeled by applying a constant lapse rate of $-0.0075^{\circ} \mathrm{C} \mathrm{m}^{-1}$ (Mihalcea and others, 2006). For the whole CKNP glacierized area, $T_{\text {a-point }}$ was calculated as

$$
T_{\text {a-point }}=T_{\text {a-Askole }}+\left(-0.0075^{\circ} \mathrm{C} \mathrm{m}^{-1}\right) \cdot \Delta z,
$$

where $\Delta z$ is the difference in altitude $(\mathrm{m})$ between the glacier pixel and Askole.

The daily mean incoming solar radiation $\left(\mathrm{SW}_{\text {in-point; }}\right.$ $\mathrm{W} \mathrm{m}^{-2}$ ) was estimated at each pixel based on the data gathered at Askole ( $\mathrm{SW}_{\text {in-Askole }}$ ) (Mihalcea and others, 2008a):

$$
\mathrm{SW}_{\text {in-point }}=\mathrm{SW}_{\text {in-Askole }}\left[1+\left(2.4 \cdot 10^{-5} \Delta z\right)\right]
$$

\subsection{Distribution of the debris thickness}

There is no fully updated map of the glaciers in the CKNP. The first Park Glacier Inventory was only recently developed from Landsat imagery dating from 2010 (Minora and others, 2013). The debris coverage within glacierized areas below 5200 ma.s.I. (i.e. the ablation zone) was assessed by the SML classification applied to Landsat TM images from 2011. This approach involved training the classification algorithm with a number of sites where the classification output (i.e. presence or absence of debris on the glacier surface) was known (Brown and others, 1998). The SML algorithm assumes that values in each spectral band from Landsat $\mathrm{TM}$ are normally distributed and calculates the probability that a given image pixel is debris-covered or debris-free based on the values of all spectral bands. Each pixel is finally classified as debris-covered or debris-free according to the class that has the highest probability (Richards, 1999). The details of the satellite images used are shown in Table 1. In particular, we used band combination 543 (as red, green, blue) of Landsat TM scenes to draw 20 regions of interest (ROIs) and trained the classifier. ROls are sample areas that we know were covered by supraglacial debris in 2011. After training, the classifier was run on all the glacierized areas of the CKNP, assuming a probability threshold of $90 \%$ to separate debris-covered from debris-free pixels (i.e. a pixel was classified as 'supraglacial debris-covered' when the probability of a pixel belonging to this class was $>0.9$ ). The remaining pixels within glacierized areas and below the ELA were considered debris-free areas.

To map the thickness of supraglacial debris over the whole glacierized area of the CKNP, we used the method developed by Mihalcea and others (2008b) for Miage glacier, Mont Blanc massif, Italy, and already applied to Baltoro glacier by Mihalcea and others (2008a). This method is based on the relationship between surface temperature and supraglacial debris thickness (Taschner and Ranzi, 2002). 


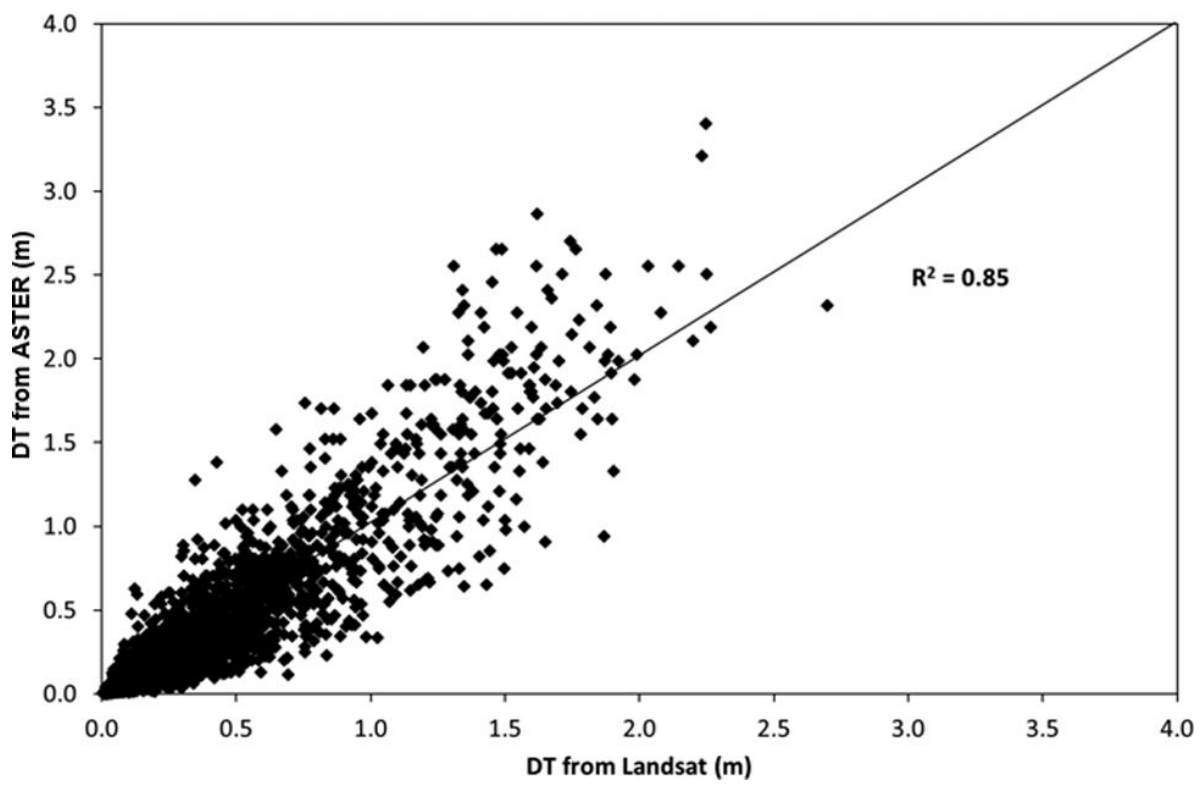

Fig. 2. Scatter plot showing DT values derived from 2004 ASTER (using equation reported in Mihalcea and others, 2008a), and the ones from 2004 Landsat (applying Eqn (5)); 8700 pixels were considered.

The input data are (1) debris thickness measured in the field on a wide and representative debris-covered glacier area and (2) satellite-derived surface temperatures. The empirical relationship between these data is a valuable tool for estimating debris thickness over unmeasured glacier zones (Mihalcea and others, 2008a,b). This approach was initially developed on ASTER temperature data acquired on 14 August 2004 and applied to Baltoro glacier by Mihalcea and others (2008a) (Table 1). Unfortunately, the ASTER images were not available for the whole CKNP area on the same date. We therefore modified the approach of Mihalcea and others $(2008 a, b)$ to use Landsat TM images covering the entire CKNP area. To evaluate the suitability for debris assessment of Landsat TM images instead of ASTER ones, firstly we processed the Landsat image of the debris-covered portion of Baltoro glacier acquired on 14 August 2004, 05:18 GMT (10:18 local time), only 28 min before the acquisition of the ASTER image analyzed by Mihalcea and others (2008a), and then we compared the results.

To assess surface temperature from Landsat images ( $\left.T_{\text {S-Landsat; }} \mathrm{K}\right)$, Landsat TM band 6 (i.e. thermal wavelength) digital numbers were first converted to radiance values $\left(R_{\text {Landsat }} ; \mathrm{W} \mathrm{m}^{-2} \mathrm{sr}^{-1} \mu^{-1}\right)$ (Coll and others, 2010), and then $T_{\text {S-Landsat }}$ was calculated applying the inverted Planck function:

$$
T_{\text {S-Landsat }}=\frac{K_{2}}{\ln \left(\frac{K_{1} \varepsilon}{R_{\text {Landsat }}}+1\right)}
$$

where $K_{1}$ and $K_{2}$ are constant values $\left(607.76 \mathrm{~W} \mathrm{~m}^{-2} \mathrm{sr}^{-1} \mu \mathrm{m}^{-1}\right.$ and $1260.56 \mathrm{~K}$, respectively; NASA, 2011), and $\varepsilon$ is the sky emissivity including atmospheric scatter (set to 0.95; Barsi and others, 2003, 2005). The temperatures estimated using the two different images showed a good correlation $\left(R^{2}=0.91\right.$; mean, maximum and minimum temperature differences $2.1 \mathrm{~K}, 14.5 \mathrm{~K}$ and $0.0 \mathrm{~K}$, respectively), thus supporting the use of Landsat data to describe supraglacial thermal conditions. Secondly, we used the same field data of debris thickness gathered in 2004 and used by Mihalcea and others (2008a) to assess the best empirical function linking Landsat 2004 thermal data and debris thickness. The best-fitting function $\left(R^{2}=0.99\right)$ is

$$
\text { DT }=\exp \left(0.17 T_{\text {S-Landsat }}-51.18\right) \text {, }
$$

where DT is debris thickness $(\mathrm{m})$ and $T_{\mathrm{S} \text {-Landsat }}$ is the Landsat-derived surface temperature. This equation is similar to that found by Mihalcea and others (2008a) and describes the nonlinear relation between debris thickness and surface temperature. Moreover, we compared DT values obtained applying the equation reported in Mihalcea and others (2008a) to 2004 ASTER data against the values derived from Eqn (5) on 2004 Landsat data on the Baltoro glacier area. The results (Fig. 2) show a good correlation between the two datasets $\left(R^{2}=0.85\right)$ and suggest a similar performance of the two models.

Hence, these preliminary tests support the suitability of Landsat-derived surface temperatures to describe supraglacial debris thickness. We therefore used the debris thickness dataset collected in the field on the surface of Baltoro glacier during an expedition in July-August 2011 (a total of 57 samples ranging from a few centimeters to $2 \mathrm{~m}$ at the tongue). Regarding the Landsat surface temperatures, a single image covering the whole CKNP was not available; therefore, we used two images acquired on 10 August 2011 05:18 GMT and on 17 August 2011 5:24 GMT (Table 1). The images selected were particularly useful for our analyses because they were taken during the same period as the field measurements, and they partly overlap; they both cover part of the Baltoro glacier tongue (where field DT data were sampled). These data allowed us to assess two empirical equations linking debris thickness measured in the field to surface temperatures derived from Landsat images. The bestfitting equation $\left(R^{2}=0.75\right)$ obtained from the image taken on 10 August 2011 (which covers the whole Baltoro glacier area) was

$$
\mathrm{DT}=\exp \left(0.16 T_{\mathrm{S} \text {-Landsat }}-49.22\right),
$$

while the one $\left(R^{2}=0.91\right)$ from the image acquired on 17 August 2011 (covering part of the Baltoro glacier tongue) was

$$
\text { DT }=\exp \left(0.20 T_{\text {S-Landsat }}-59.97\right) \text {. }
$$


We then applied Eqn (6) to thermal data derived from the Landsat image acquired on 10 August 2011, and Eqn (7) to thermal data derived from the Landsat image acquired on 17 August 2011. For the area covered by both overlapping images, results from Eqn (6) applied to the 10 August image were preferred because Baltoro glacier was only partially covered by the 17 August image, while it was completely covered by the 10 August image. Thus, the use of results from the 10 August image provided consistent estimates of the supraglacial debris thicknesses over the whole ablation area of Baltoro glacier.

\subsection{Melt over debris-covered areas}

The amount of ice melt under a debris cover ( $M_{\text {DC-point; }}$ mw.e.) depends on the energy available at the debris-ice interface and can be estimated as

$$
M_{\text {DC-point }}=\frac{G_{\text {point }} \Delta t}{\rho_{\mathrm{i}} L_{\mathrm{m}}},
$$

where $G_{\text {point }}$ corresponds to the conductive heat flux $\left(\mathrm{W} \mathrm{m}^{-2}\right), \Delta t$ is the time step, $\rho_{\mathrm{i}}$ is the ice density $\left(917 \mathrm{~kg} \mathrm{~m}^{-3}\right)$ and $L_{\mathrm{m}}$ is the latent heat of melting $(3.34 \times$ $10^{5} \mathrm{~J} \mathrm{~kg}^{-1}$ ). According to Mihalcea and others (2008a), $G_{\text {point }}$ can be estimated assuming a linear temperature gradient from the top of the debris layer to the ice surface for mean daily conditions (Nakawo and Young, 1981; Nakawo and Takahashi, 1982; Mihalcea and others, 2008a):

$$
G_{\text {point }}=\frac{\left(T_{\text {S-point }}-T_{\mathrm{i}}\right)}{\mathrm{DR}_{\text {point }}}
$$

where $T_{\mathrm{i}}$ is the ice temperature (set to the melting point, $0^{\circ} \mathrm{C}$; i.e. we neglected refreezing phenomena, which generally do not occur during the main ablation season; Mihalcea and others, 2006, 2008a) and $\mathrm{DR}_{\text {point }}$ is the effective thermal resistance of the debris layer $\left(\mathrm{m}^{2}{ }^{\circ} \mathrm{CW}^{-1}\right)$.

To derive $\mathrm{DR}_{\text {point }}$ Over the whole debris-covered glacier area, an empirical relationship was applied (Mihalcea and others, 2008a):

$$
\mathrm{DR}_{\text {point }}=19.841 \mathrm{DT}_{\text {point }}+1.0262
$$

$\mathrm{DR}_{\text {point }}$ can be assumed constant over an ablation season as it mainly depends on debris thickness, which is generally considered stable over short periods (1-2 months; Fyffe and others, 2014). To model the daily mean debris surface temperature at each pixel ( $\left.T_{\mathrm{S} \text {-point }}\right)$, we considered both daily incoming solar radiation $\left(\mathrm{SW}_{\text {in-point }}\right)$ and debris thickness $\left(\mathrm{DT}_{\text {point }}\right)$, because higher radiation and thicker debris lead to higher surface temperatures (Mihalcea and others, 2006, 2008a,b; Mayer and others, 2010). $T_{\text {S-point }}$ was estimated according to the empirical function

$$
T_{\text {S-point }}=13.1667 \mathrm{DT}_{\text {point }}+0.0352 \mathrm{SW}_{\text {in-point }}
$$

with a root-mean-square error (RMSE) of $2.1^{\circ} \mathrm{C}$. This relation was based on field data of debris thickness and surface temperature sampled on Baltoro glacier during summer 2011 and incoming solar radiation estimated in the same gridpoints. Finally, the daily ablation ( $M_{\text {DC-point; }} \mathrm{m}$ w.e.) at each pixel of the CKNP debris-covered glacier area was modeled as

$$
M_{\text {DC-point }}=\frac{T_{\text {S-point }}}{\mathrm{DR}_{\text {point }}} \frac{1}{L_{\mathrm{m}} \rho_{\mathrm{i}}} \Delta t,
$$

where $\Delta t$ is the number of seconds in a day $\left(8.64 \times 10^{4}\right)$.

\subsection{Melt over debris-free areas}

The daily ice melt at each pixel with debris-free ice $\left(M_{D F}\right.$ point) was estimated by applying an enhanced $T$-index model (Pellicciotti and others, 2005):

$M_{\text {DF-point }}\left\{\begin{array}{cl}\text { TMF } \cdot T_{\text {a-point }}+\mathrm{RMF} \cdot(1-\alpha) \cdot \mathrm{SW}_{\text {in-point }} & T_{\mathrm{a}} \leq 0^{\circ} \mathrm{C} \\ 0 & T_{\mathrm{a}}>0^{\circ} \mathrm{C}\end{array}\right.$

where $T_{\text {a-point }}$ is the daily mean air temperature $\left({ }^{\circ} \mathrm{C}\right), \alpha$ is the surface albedo, $\mathrm{SW}_{\text {in-point }}$ is the daily mean incoming solar radiation $\left(\mathrm{W} \mathrm{m}^{-2}\right)$, and TMF $\left(32.43 \times 10^{-4} \mathrm{~m} \mathrm{~d}^{-1}{ }^{\circ} \mathrm{C}^{-1}\right)$ and RMF $\left(0.79 \times 10^{-4} \mathrm{md}^{-1} \mathrm{~W}^{-1} \mathrm{~m}^{2}\right)$ are the temperature and radiative melting factors, respectively. These melting factors are assessed from ablation measured at some selected sites on Baltoro glacier (from 3939 to 5200 m a.s.l.) from 23 July to 7 August 2011 (Table 2). Melting factors estimated from field data are taken as constant in time and space (Hock, 1999). Albedo was estimated by analyzing incoming and outgoing solar radiation data recorded during 2012 by a net radiometer (CNR1, Kipp \& Zonen) installed at the Concordia supraglacial AWS. The spectral range considered was 0.3$3 \mu \mathrm{m}$. Data show a high debris-free ice reflectivity, with a mean value of 0.30 . Since distributed outgoing solar radiation data are not available for Baltoro glacier, we used the mean albedo value observed at Concordia. A lower ice reflectivity may be due to the presence of water, dust, debris and organic matter increasing the absorbed solar radiation and therefore the melting rate. Consequently, our assumption of a constant albedo equal to 0.30 may have led to a slight underestimation of the amount of meltwater, i.e. if the glacier ice is not completely clean in some parts of its debris-free area.

In any case, it is worth noting that other authors applying enhanced $T$-index approaches have also used constant albedo values (e.g. Pellicciotti and others, 2005).

\section{RESULTS}

Modeled meteorological variables (Eqns (2) and (3)) agree well with those measured at Urdukas in 2011 and at Concordia in 2012. RMSEs regarding air temperature datasets are found equal to $1.2^{\circ} \mathrm{C}$ (for Urdukas) and $1.3^{\circ} \mathrm{C}$ (for Concordia), indicating that the local gradient by Mihalcea and others (2006) can be considered accurate (Fig. 3). Modeled incoming solar radiation values resulted in a good match with the measured ones (Fig. 4), with RMSE values of 39 and $125 \mathrm{~W} \mathrm{~m}^{-2}$ for Urdukas and Concordia, respectively.

Supraglacial debris covers $518.47 \mathrm{~km}^{2}$ (16.5\%, 576072 pixels) of the ablation zone of all the CKNP glaciers, while the extent of the debris-free area was $2619.61 \mathrm{~km}^{2}$ (2910672 pixels). An example of debris occurrence is shown in Figure 5, where Panmah glacier (located in the central part of the CKNP, northwest of Baltoro glacier) is displayed. As regards the supraglacial debris thickness (Fig. 6), a mean value of $0.23 \mathrm{~m}$ was found, with maxima of $\sim 3 \mathrm{~m}$.

During the 2011 ablation season, we collected 29 measurements on Baltoro glacier (both debris-covered and debris-free conditions). We divided this dataset into two subgroups: one for calibrating our melt models and the other for validating them. Table 2 reports the two sub-datasets used to calibrate and validate the models. 


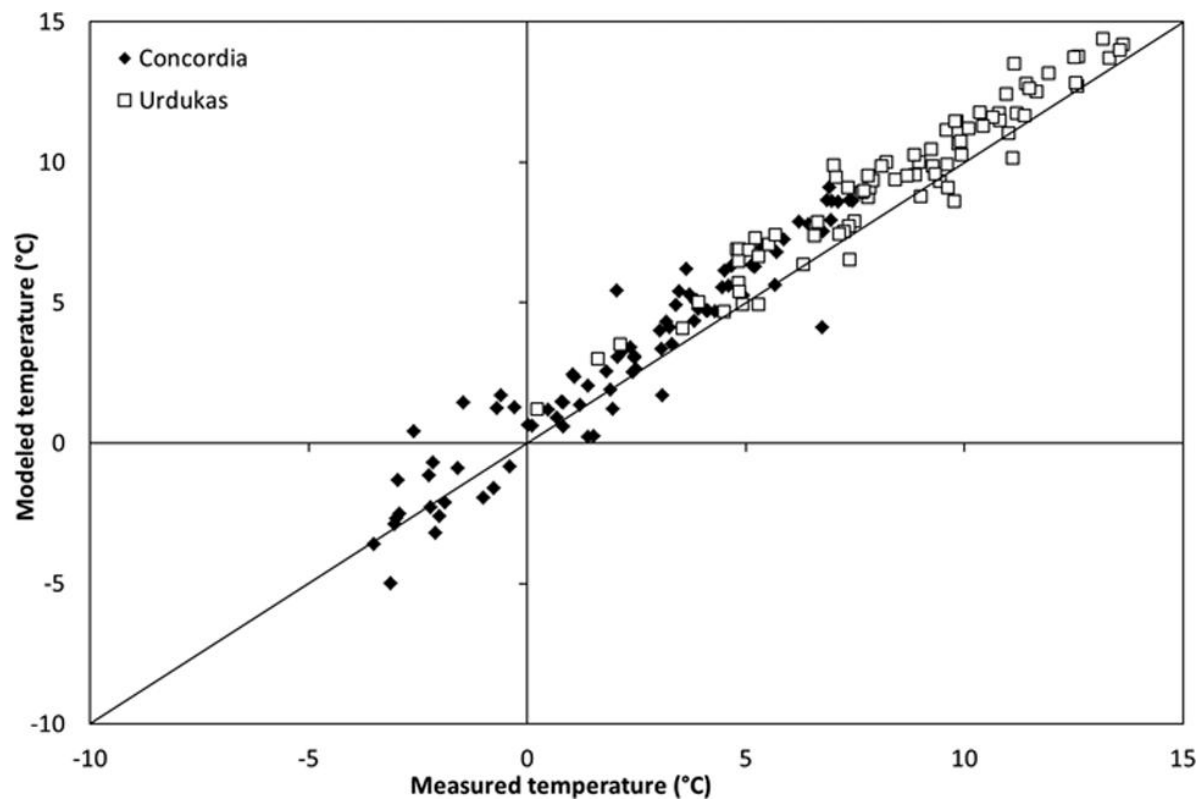

Fig. 3. Daily mean temperatures recorded by the AWS installed at Urdukas during 2011 ( $x$-axis) vs modeled daily mean temperatures ( $y$-axis) obtained by applying a constant local lapse rate of $-0.0075^{\circ} \mathrm{C} \mathrm{m}^{-1}$ to Askole temperatures (open box). The same analysis was performed for the Concordia dataset during 2012 (solid diamond).

Table 2. Dataset used to calibrate and validate melt models. Dataset indicates whether ablation recorded at that site was used to calibrate (C) or to validate (V) the models; the site was debris-covered (DC) or debris-free (DF); Elev: elevation (ma.s.I.); $X$ and $Y$ : projected coordinates (WGS84UTM zone 43N); DR: debris effective thermal resistance $\left(\mathrm{m}^{2}{ }^{\circ} \mathrm{CW}^{-1}\right)$; DT-res and $M$-res: debris-thickness and melt residuals (modeled minus observed values); err: melt residual (\%). The period considered is from the end of July to mid-August

\begin{tabular}{|c|c|c|c|c|c|c|c|c|c|c|c|}
\hline Dataset-Debris & Elev. & $X$ & Y & DT-observed & DT-modeled & DT-res & $\mathrm{DR}$ & M-observed & M-modeled & $M$-res & err \\
\hline C-DC1 & 3699 & 606400 & 3952497 & 0.38 & 0.55 & +0.17 & 8.47 & 0.12 & 0.15 & +0.04 & $+30 \%$ \\
\hline C-DC2 & 3822 & 610488 & 3953487 & 0.32 & 0.43 & +0.11 & 7.28 & 0.14 & 0.18 & +0.04 & $+26 \%$ \\
\hline C-DC3 & 3923 & 613550 & 3954650 & 0.13 & 0.17 & +0.04 & 3.61 & 0.40 & 0.29 & -0.11 & $-28 \%$ \\
\hline C-DC4 & 3980 & 615221 & 3955685 & 0.26 & 0.14 & -0.06 & 6.18 & 0.25 & 0.21 & -0.04 & $-16 \%$ \\
\hline C-DF1 & 3939 & 612778 & 3954341 & 0.00 & - & - & - & 0.85 & 0.85 & 0.00 & $0 \%$ \\
\hline C-DF2 & 4554 & 636142 & 3956930 & 0.00 & - & - & - & 0.62 & 0.61 & -0.01 & $-1 \%$ \\
\hline C-DF3 & 5200 & 639556 & 3968575 & 0.00 & - & - & - & 0.00 & 0.34 & +0.34 & - \\
\hline C-AVE & & & & & & +0.07 & & & & +0.04 & $+2 \%$ \\
\hline C-RMSE & & & & & & +0.11 & & & & +0.14 & $+25 \%$ \\
\hline V-DC1 & 3985 & 616248 & 3955171 & 0.03 & 0.10 & +0.07 & 1.52 & 0.64 & 0.48 & -0.16 & $-25 \%$ \\
\hline V-DC2 & 3997 & 616148 & 3955855 & 0.15 & 0.41 & +0.26 & 4 & 0.24 & 0.21 & -0.03 & $-11 \%$ \\
\hline V-DC3 & 4008 & 616056 & 3956353 & 0.02 & 0.20 & +0.18 & 1.42 & 0.59 & 0.51 & -0.08 & $-13 \%$ \\
\hline V-DC4 & 4188 & 623369 & 3956355 & 0.41 & 0.11 & -0.30 & 9.16 & 0.11 & 0.12 & +0.01 & $+11 \%$ \\
\hline V-DC5 & 4077 & 618774 & 3955909 & 0.03 & 0.25 & +0.22 & 1.62 & 0.49 & 0.46 & -0.03 & $-7 \%$ \\
\hline V-DC6 & 4163 & 621318 & 3955889 & 0.11 & 0.00 & -0.11 & 3.21 & 0.27 & 0.26 & -0.01 & $-5 \%$ \\
\hline V-DC7 & 4178 & 623804 & 3955827 & 0.02 & 0.08 & +0.06 & 1.42 & 0.46 & 0.52 & +0.06 & $+12 \%$ \\
\hline V-DC8 & 4178 & 623801 & 3955858 & 0.02 & 0.05 & +0.03 & 1.42 & 0.49 & 0.52 & +0.03 & $+5 \%$ \\
\hline V-DC9 & 4178 & 623798 & 3955889 & 0.01 & 0.05 & +0.04 & 1.23 & 0.48 & 0.59 & +0.11 & $+23 \%$ \\
\hline V-DC10 & 4178 & 623808 & 3955914 & 0.04 & 0.05 & +0.01 & 1.82 & 0.40 & 0.41 & +0.02 & $+5 \%$ \\
\hline V-DC11 & 4178 & 623813 & 3955942 & 0.02 & 0.05 & +0.03 & 1.42 & 0.49 & 0.52 & +0.03 & $+5 \%$ \\
\hline V-DC12 & 4178 & 623833 & 3955939 & 0.05 & 0.05 & 0.00 & 2.02 & 0.38 & 0.38 & 0.00 & $-1 \%$ \\
\hline V-DC13 & 4178 & 623851 & 3955914 & 0.06 & 0.05 & -0.01 & 2.22 & 0.30 & 0.35 & +0.05 & $+16 \%$ \\
\hline V-DC14 & 4178 & 623807 & 3955982 & 0.01 & 0.05 & +0.04 & 1.23 & 0.58 & 0.59 & +0.01 & $+2 \%$ \\
\hline V-DC15 & 4178 & 623818 & 3955951 & 0.01 & 0.05 & +0.04 & 1.23 & 0.48 & 0.59 & +0.12 & $+24 \%$ \\
\hline V-DC16 & 4178 & 623878 & 3956476 & 0.10 & 0.17 & +0.07 & 3.01 & 0.35 & 0.27 & -0.08 & $-23 \%$ \\
\hline V-DF1 & 4181 & 623382 & 3955368 & 0 & - & - & - & 0.47 & 0.49 & +0.02 & $+4 \%$ \\
\hline V-DF2 & 4178 & 623848 & 3955914 & 0 & - & - & - & 0.37 & 0.49 & +0.12 & $+32 \%$ \\
\hline V-DF3 & 4178 & 623830 & 3955979 & 0 & - & - & - & 0.56 & 0.49 & -0.07 & $-13 \%$ \\
\hline V-DF4 & 4178 & 623832 & 3955985 & 0 & - & - & - & 0.54 & 0.49 & -0.05 & $-9 \%$ \\
\hline V-DF5 & 4178 & 623827 & 3956013 & 0 & - & - & - & 0.64 & 0.49 & -0.15 & $-23 \%$ \\
\hline V-DF6 & 4178 & 623894 & 3956430 & 0 & - & - & - & 0.39 & 0.49 & +0.10 & $+26 \%$ \\
\hline V-AVE & & & & 0.07 & 0.11 & +0.04 & & & & 0.00 & $+2 \%$ \\
\hline V-RMSE & & & & & & +0.13 & & & & +0.08 & $+16 \%$ \\
\hline AVE & & & & & & +0.04 & & & & +0.01 & $+2 \%$ \\
\hline RMSE & & & & & & +0.13 & & & & +0.09 & $+17 \%$ \\
\hline
\end{tabular}




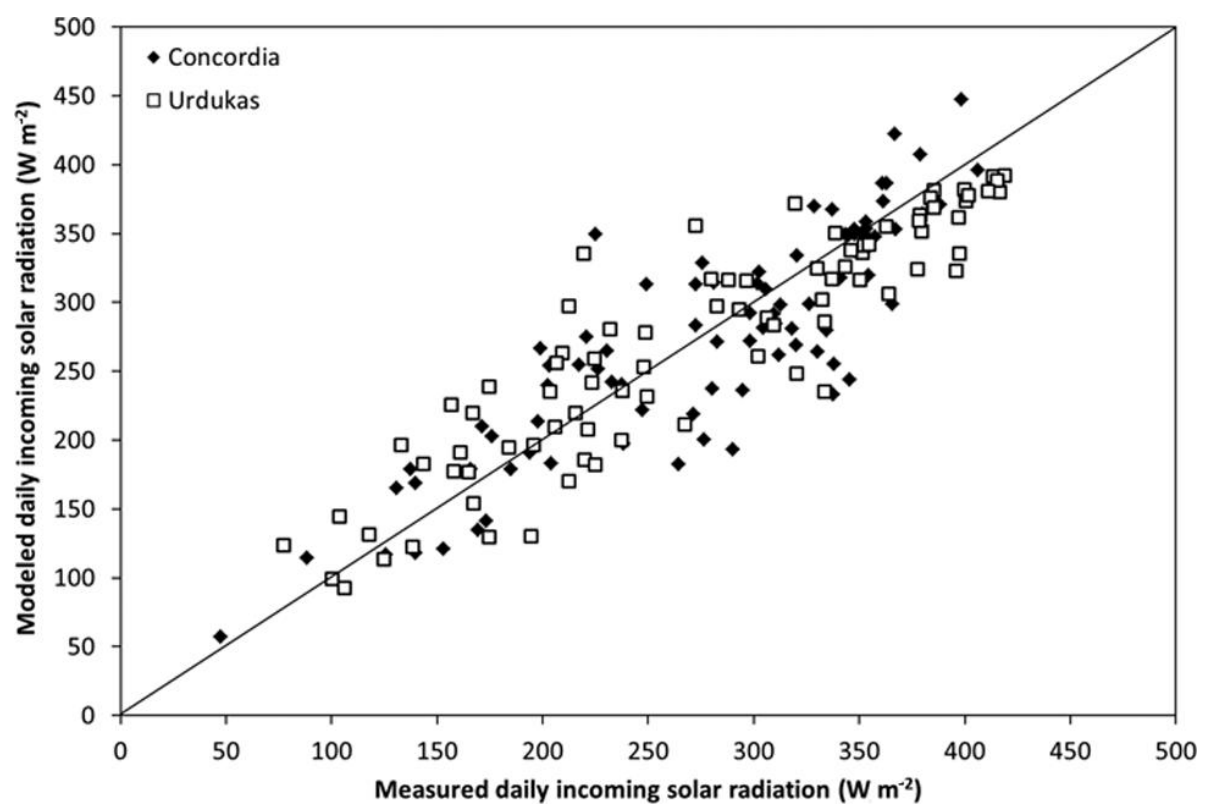

Fig. 4. Daily mean incoming solar radiation recorded by the AWSs installed at Urdukas during 2011 and at Concordia during 2012 (x-axis) vs the modeled values ( $y$-axis) derived from Askole data.

The validation indexes display the performance of our models for estimating debris-free and debris-covered ice melt. In particular, we found a mean error of $+0.01 \mathrm{~m}$ w.e. (corresponding to $2 \%$ ) and a RMSE equal to $0.09 \mathrm{~m}$ w.e. $(17 \%)$. In addition, we assessed any error due to the methodology applied for distributing the meteorological variables. For this purpose, we calculated the melt amount at selected debris-free (C-DF1, C-DF2, C-DF3) and debriscovered (C-DC1, C-DC2, C-DC3, C-DC4) ice field points varying the meteorological model inputs $\left(T_{\mathrm{a}}, T_{\mathrm{S}}\right.$ and $\mathrm{SW}$ in $)$ by their maximum RMSE (i.e. $\pm 1.3^{\circ} \mathrm{C}, \pm 2.1^{\circ} \mathrm{C}$ and $\pm 125 \mathrm{~W} \mathrm{~m}^{-2}$, respectively). Changing $T_{\mathrm{a}}$ and $\mathrm{SW}_{\mathrm{in}}$, the debris-free ice melt variations range from $\pm 10 \%$ to $\pm 25 \%$ (at higher altitudes); debris-covered ice melt instead shows differences around $\pm 30 \%$ when changing $\mathrm{SW}_{\mathrm{in}}$, while variations in $T_{\mathrm{S}}$ drive a lower alteration around $\pm 15 \%$, not particularly influenced by elevation. Thus, the debris-covered ice melt model is more sensitive to the errors in the meteorological input data. However, debris-covered ice melt accounts for only $11 \%$ of the total melt. Moreover, these error tests were made considering the worst cases (maximum RMSE).
The debris-covered and debris-free ice melt models were therefore applied to the whole glacierized area of the CKNP below the ELA. The results are shown in Figure 7.

Given that the solar radiation was used to estimate debris surface temperatures, affecting in turn conductive heat fluxes, melt in debris-covered areas $\left(M_{\mathrm{DC}}\right)$ was largely linked to incoming solar radiation $\left(\mathrm{SW}_{\mathrm{in}}\right)$. Indeed, the minimum and maximum daily melt $(0.005$ and 0.089 mw.e., respectively) occurred during days with the lowest and highest incoming solar radiation (respectively, 112 and $371 \mathrm{~W} \mathrm{~m}^{-2}$, in Askole; Fig. 8a). Conversely, melting in debris-free areas showed extreme daily values (0.009 and $0.110 \mathrm{mw}$.e.) in days with extreme air temperatures (respectively $+14.1^{\circ} \mathrm{C}$ and $+22.7^{\circ} \mathrm{C}$ recorded at Askole; Fig. 8b). Overall, the greatest ablation occurred on 5 August, when incoming solar radiation was high, but not the highest, while the minima occurred on days (28-31 July) with minimum radiative input.

These findings indicate that (1) melt from the debriscovered parts of the glaciers $\left(M_{\mathrm{DC}}\right)$ is mostly influenced by the incoming solar radiation, since it depends on the

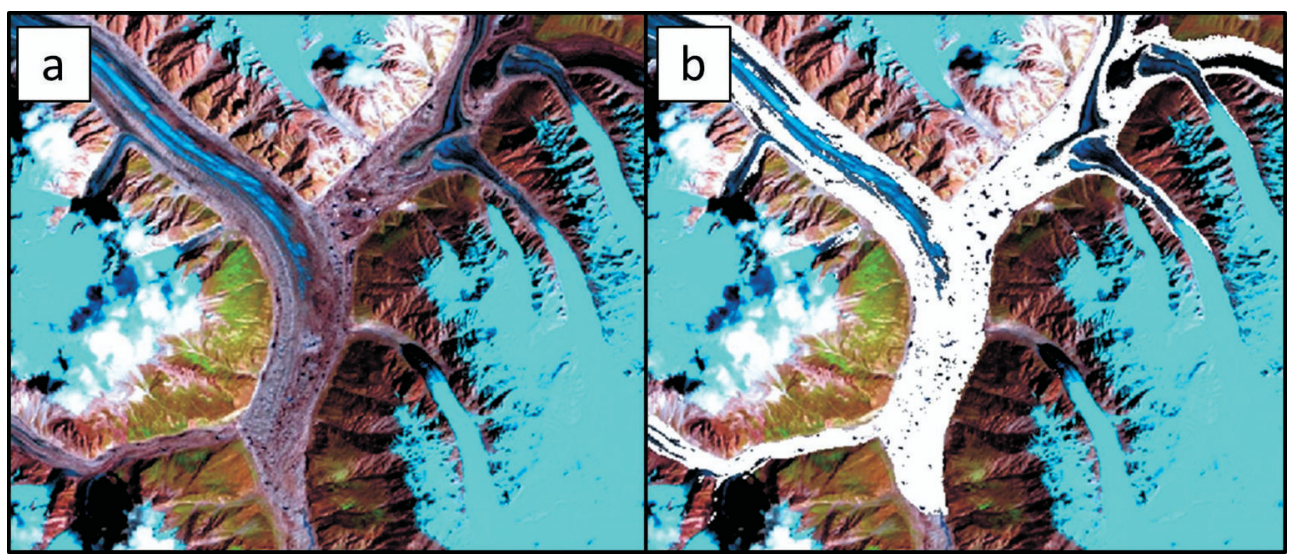

Fig. 5. (a) Landsat $T M$ image with $R G B=543$ of portion of Panmah glacier. (b) The same image with pixels classified as covered by supraglacial debris highlighted in white. 


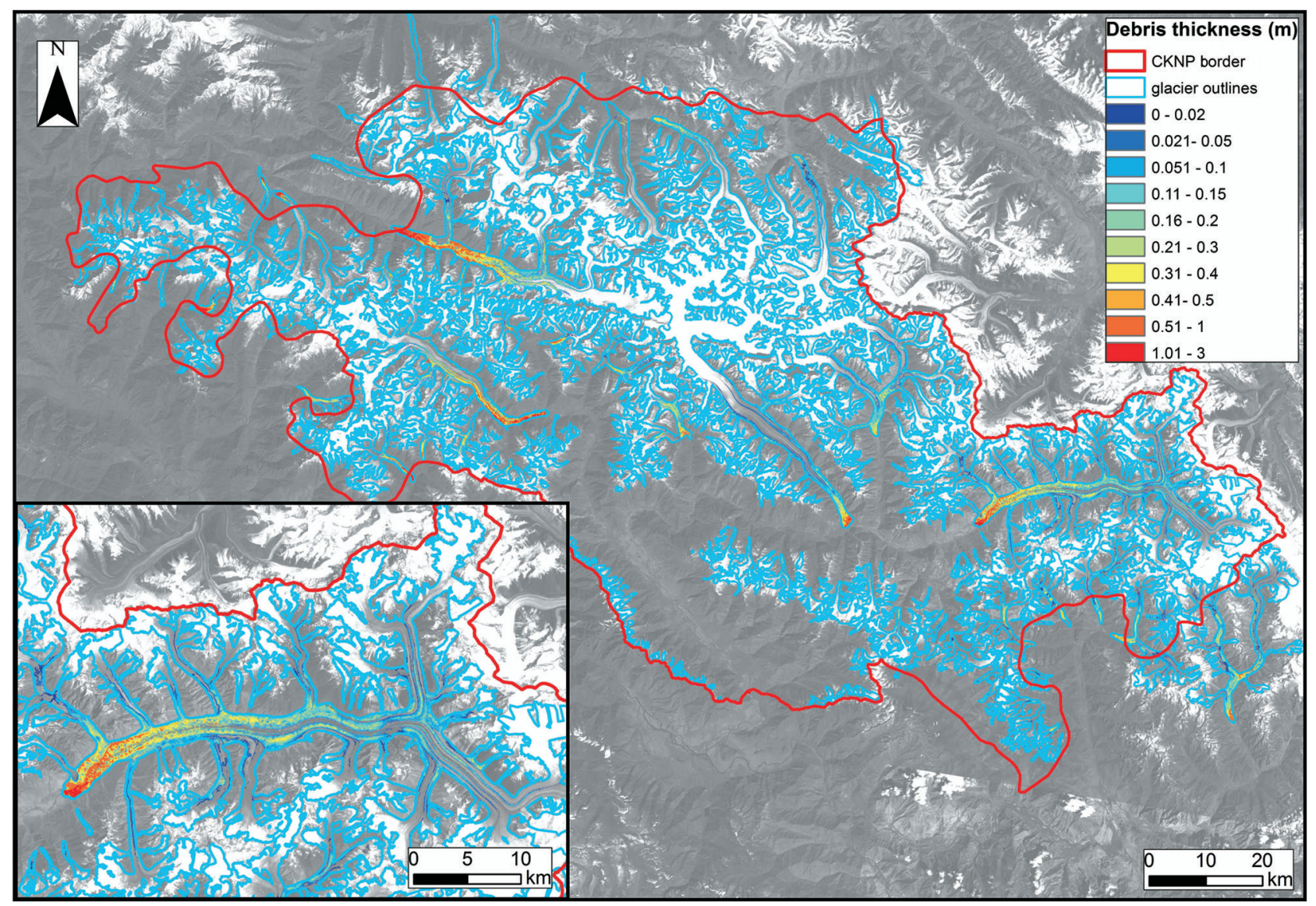

Fig. 6. Map showing the supraglacial debris thicknesses over CKNP area, and a zoom on Baltoro glacier (lower left box).

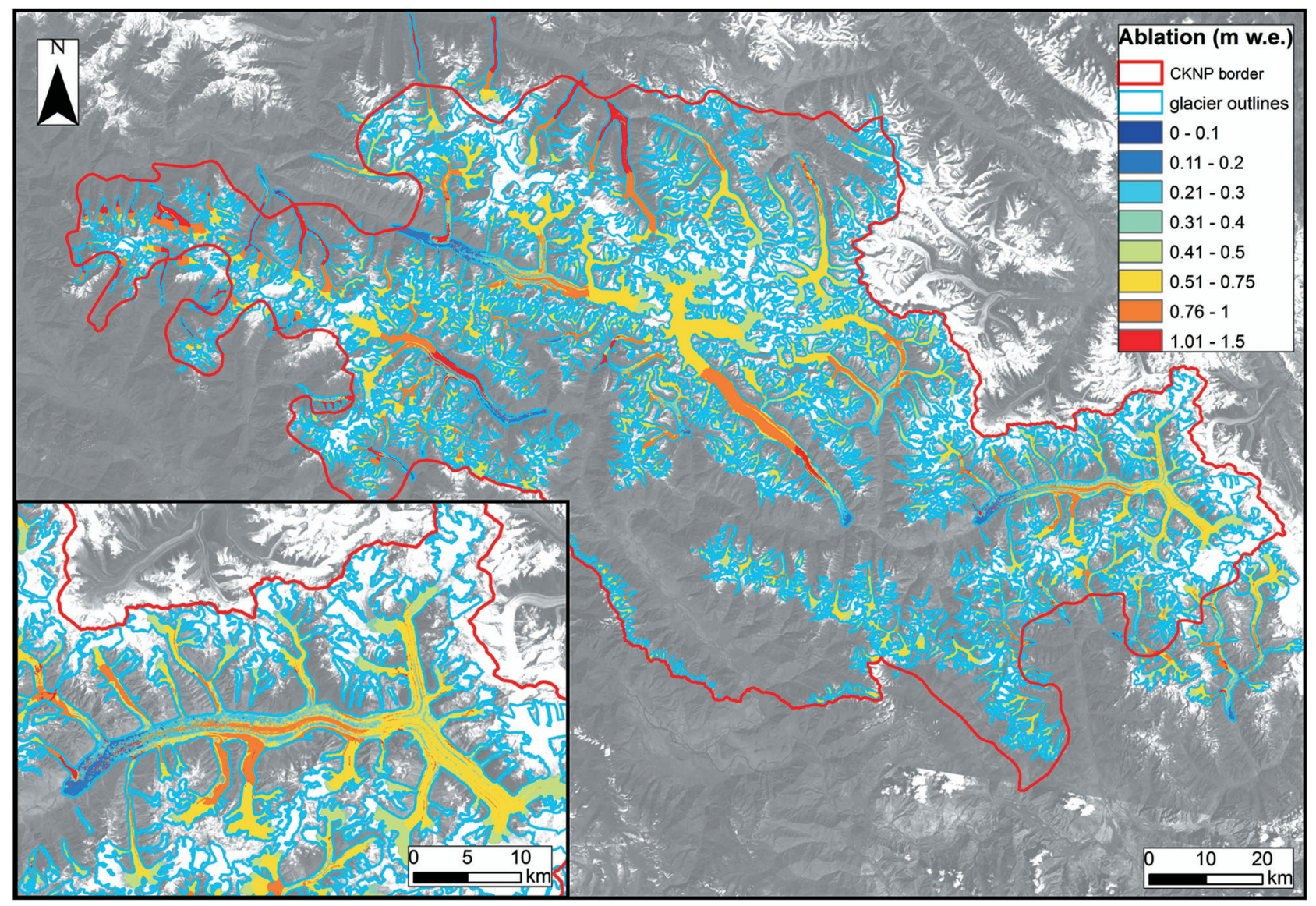

Fig. 7. Ablation map of CKNP glaciers below the ELA in the period 23 July-9 August 2011, and a zoom on Baltoro glacier (lower left box). 

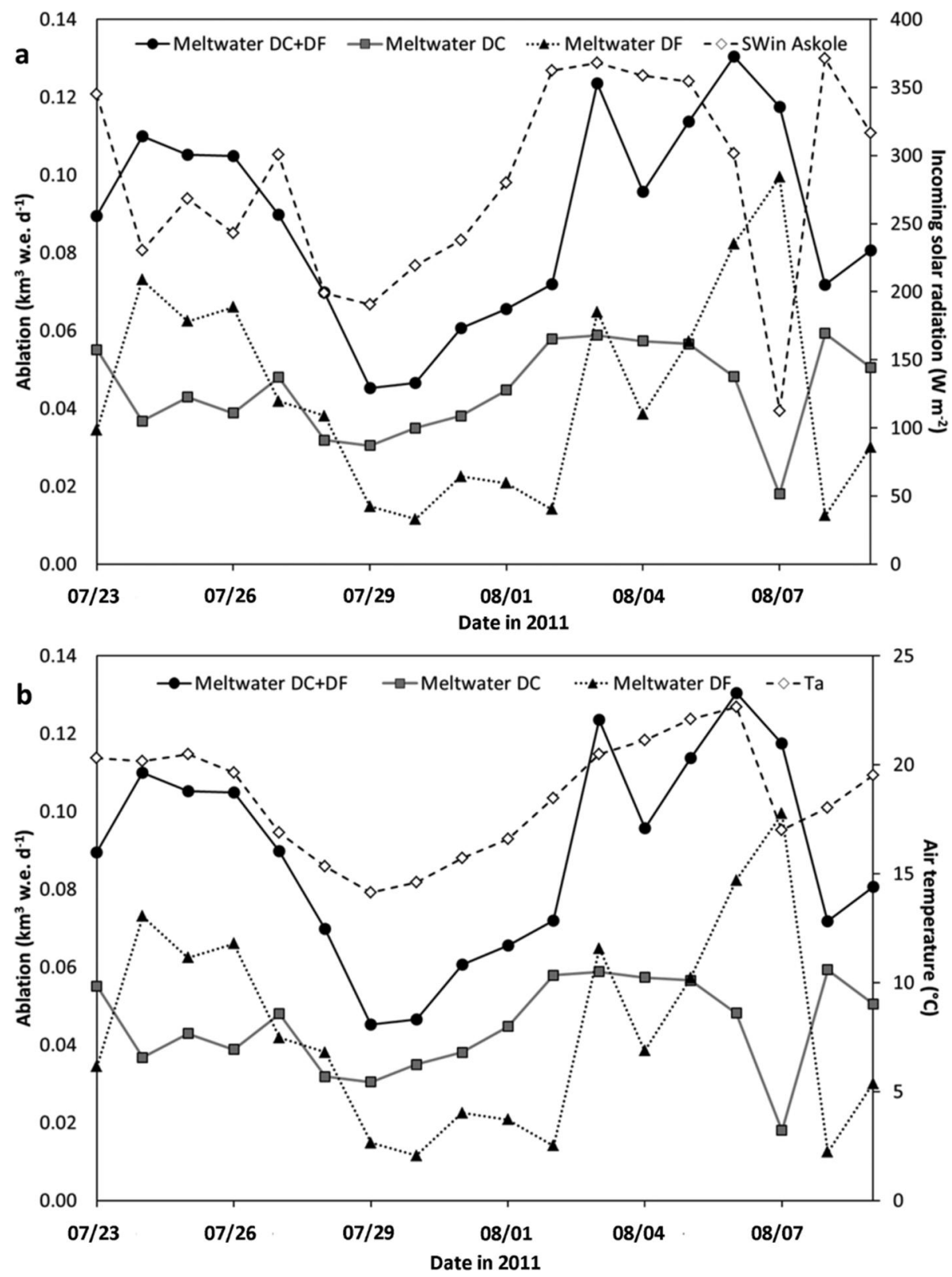

Fig. 8. Daily meltwater production from 23 July to 9 August 2011 from all the CKNP glaciers over the debris-free (DF) and debris-covered (DC) areas and the total (DC + DF). Same data are presented with (a) daily incoming solar radiation (SW) and (b) daily mean air temperature (Ta) recorded at Askole. Date format is $\mathrm{mm} / \mathrm{dd}$.

conductive heat flux, and (2) melt of debris-free parts of the glaciers $\left(M_{\mathrm{DF}}\right)$ is more sensitive to air temperature.

On debris-covered areas of the whole CKNP, the daily average ablation was $0.024 \mathrm{mw}_{\text {we. }} \mathrm{d}^{-1}$, while on debris-free areas it was $0.037 \mathrm{~m}$ w.e. $\mathrm{d}^{-1}$. Considering both debris-free and debris-covered areas in the whole CKNP and the entire analyzed period, we estimated a total melt of 0.63 m w.e., corresponding to an average ablation of $0.035 \mathrm{mw}$.e. $\mathrm{d}^{-1}$. Hence, over the period we considered, melting of the debris-covered parts of all the glaciers in the CKNP produced $0.223 \mathrm{~km}^{3}$ of meltwater (total $M_{\mathrm{DC}}$ ), with a daily average of $0.012 \mathrm{~km}^{3}$ w.e. $\mathrm{d}^{-1}$. The total meltwater from the debris-free parts (total $M_{\mathrm{DF}}$ ) was $1.740 \mathrm{~km}^{3}$, with an average of $0.097 \mathrm{~km}^{3} \mathrm{~d}^{-1}$. The total ice melt from the CKNP was thus equal to $1.963 \mathrm{~km}^{3}$ w.e., with a daily average of $0.109 \mathrm{~km}^{3}$ w.e. $\mathrm{d}^{-1}$. This water volume equals $\sim 14 \%$ of the reservoir capacity of the Tarbela Dam, a very large dam on the Indus River that plays a key role for irrigation, flood control and the generation of hydroelectric power for
Pakistan (Thompson, 1974). Table 3 shows a summary of the model results.

Table 3. Modeled melt rates over debris-covered (DC) and debrisfree (DF) areas, and the total ablation in the period 23 July-9 August 2011

\begin{tabular}{lccc}
\hline & DC & DF & Total \\
\hline Area $\left(\mathrm{km}^{2}\right)$ & 518 & 2620 & 3138 \\
Min daily $M\left(\mathrm{~m}\right.$ w.e. $\left.\mathrm{d}^{-1}\right)$ & 0.011 & 0.016 & 0.011 \\
Max daily $M\left(\mathrm{~m}\right.$ w.e. $\left.\mathrm{d}^{-1}\right)$ & 0.031 & 0.053 & 0.031 \\
Mean daily $M\left(\mathrm{~m}^{-1}\right.$ w.e. $\left.\mathrm{d}^{-1}\right)$ & 0.024 & 0.037 & 0.035 \\
$M(\mathrm{~m}$ w.e. $)$ & 0.432 & 0.666 & 0.630 \\
Min daily $M\left(\mathrm{~km}^{3}\right.$ w.e. $\left.\mathrm{d}^{-1}\right)$ & 0.006 & 0.041 & 0.006 \\
Max daily $M\left(\mathrm{~km}^{3}\right.$ w.e. $\left.\mathrm{d}^{-1}\right)$ & 0.016 & 0.139 & 0.139 \\
Mean daily $M\left(\mathrm{~km}^{3}\right.$ w.e. $\left.\mathrm{d}^{-1}\right)$ & 0.012 & 0.097 & 0.109 \\
$M\left(\mathrm{~km}^{3}\right)$ & 0.223 & 1.740 & 1.963 \\
\hline
\end{tabular}


Table 4. Sensitivity tests performed by applying different input data to the debris-covered ice melt model. We applied the model to four points where actual ablation data were collected in the field (the calibration points in Table 2) and calculated melt anomalies $(\Delta M)$ with respect to $M_{\mathrm{DC}}$ by modifying the incoming shortwave radiation and debris thickness. The reference modeled melt is given by $M_{\mathrm{DC}} \bmod$

\begin{tabular}{|c|c|c|c|c|}
\hline & C-DC1 & C-DC2 & C-DC3 & C-DC4 \\
\hline Elevation (ma.s.I.) & 3699 & 3822 & 3923 & 3980 \\
\hline Debris thickness (cm) & 37.5 & 31.5 & 13.0 & 26.0 \\
\hline Time frame (days) & 11 & 12 & 12 & 13 \\
\hline$M$ meas (mw.e.) & 0.12 & 0.14 & 0.4 & 0.25 \\
\hline $\mathrm{DR}\left({ }^{\circ} \mathrm{C} \mathrm{m}^{2} \mathrm{~W}^{-1}\right)$ & 8.47 & 7.28 & 3.61 & 6.18 \\
\hline$M_{\mathrm{DC}} \bmod (\mathrm{m} w . e)$. & 0.15 & 0.18 & 0.29 & 0.21 \\
\hline$\Delta M_{+10 \% \text { swin }}$ (mw.e.) & 0.01 & 0.013 & 0.025 & 0.016 \\
\hline$\Delta M_{-10 \%}$ swin $(\mathrm{m}$ w.e.) & 0.01 & 0.013 & 0.025 & 0.016 \\
\hline$\Delta M$ ave $\% \pm 10 \%$ swin & \pm 6.7 & \pm 8.7 & \pm 16.7 & \pm 10.7 \\
\hline$\Delta M_{+20 \% \text { swin }}$ (mw.e.) & 0.021 & 0.025 & 0.05 & 0.031 \\
\hline$\Delta M_{-20 \%}$ swin (mw.e.) & 0.021 & 0.025 & 0.012 & 0.031 \\
\hline$\Delta M$ ave $\%{ }_{ \pm 2} 0 \%$ swin & \pm 14 & \pm 16.7 & \pm 20.7 & \pm 20.7 \\
\hline$\Delta M_{+10 \% \text { DT }}(\mathrm{m}$ w.e. $)$ & 0.008 & 0.009 & 0.015 & 0.011 \\
\hline$\Delta M_{-10 \% \text { DT }}$ (m w.e.) & 0.009 & 0.011 & 0.018 & 0.013 \\
\hline$\Delta M$ ave $\%{ }_{ \pm 10 \% \mathrm{DT}}$ & \pm 5.7 & \pm 6.7 & \pm 11.0 & \pm 8.0 \\
\hline$\Delta M_{+1 \mathrm{~cm} \text { DT }}(\mathrm{m}$ w.e. $)$ & 0.002 & 0.003 & 0.012 & 0.005 \\
\hline$\Delta M_{-1 \mathrm{~cm} \text { DT }}(\mathrm{m}$ w.e. $)$ & 0.002 & 0.003 & 0.013 & 0.005 \\
\hline$\Delta M$ ave $\%=1 \mathrm{~cm}$ DT & \pm 1.3 & \pm 2.0 & \pm 8.3 & \pm 3.3 \\
\hline$\Delta M_{+5 \mathrm{~cm} \text { DT }}(\mathrm{m}$ w.e. $)$ & 0.01 & 0.014 & 0.05 & 0.02 \\
\hline$\Delta M_{-5 \mathrm{~cm} \text { DT }}$ (m w.e.) & 0.013 & 0.019 & 0.088 & 0.028 \\
\hline$\Delta M$ ave $\%{ }_{ \pm 5} \mathrm{~cm}$ DT & \pm 7.7 & \pm 11.0 & \pm 46.0 & \pm 16.0 \\
\hline$\Delta M_{+10 \mathrm{~cm} \mathrm{DT}}(\mathrm{m}$ w.e. $)$ & 0.018 & 0.025 & 0.082 & 0.035 \\
\hline$\Delta M_{-10 \mathrm{~cm} \mathrm{DT}}(\mathrm{m}$ w.e. $)$ & 0.029 & 0.044 & 0.283 & 0.069 \\
\hline$\Delta M$ ave $\%{ }_{ \pm 10 \mathrm{~cm} \text { DT }}$ & \pm 15.7 & \pm 23.0 & \pm 121.7 & \pm 34.7 \\
\hline
\end{tabular}

\section{DISCUSSION}

Supraglacial debris thickness was derived from Landsat thermal data $(60 \mathrm{~m} \times 60 \mathrm{~m}$ pixel size), limiting the spatial resolution of debris-covered ice melt calculations. The results could, however, be acceptable given the extent of the analyzed debris-covered area $\left(518 \mathrm{~km}^{2}\right)$. The obtained DT values were cross-checked against a selection of field data, and a good fit was found (see Table 2). The main limitation comes from the fact that the supraglacial debris thicknesses derived from Landsat thermal data are average values at the pixel scale. The approach does not consider meltwater ponds, supraglacial lakes and sectors with crevasses and ice seals covering glacier areas smaller than the pixel size. Consequently, the model performs better in estimating debris layers thicker than $0.1 \mathrm{~m}$ (i.e. debris coverage is relatively continuous), while slight overestimation occurs for thin and sparse debris areas $(<0.1 \mathrm{~m}$; Table 2$)$. The same limitation in DT modeling by means of remote sensing was found by Mihalcea and others (2008a).

Mapping of debris thickness is fundamental for estimating debris resistivity, and therefore debris-covered ice melt. Other approaches have been proposed to produce debris thickness maps at higher resolution than ours (Foster and others, 2012), but they require meteorological data (including, among others, wind speed and direction and turbulent heat fluxes) on the glacier surface, as well as high-resolution DEMs (e.g. from lidar surveys), which were not available for glaciers in the CKNP area. Hence, our simple approach is suitable for investigating a wide and remote glacier area where high-resolution information is not available.
Table 5. Sensitivity tests performed by applying different input data to the debris-free ice melt model. We applied the model to three points where actual ablation data were collected in the field (the calibration points in Table 2) and calculated melt anomalies $(\Delta M)$ with respect to $M_{\mathrm{DF}}$ by varying the air temperature, the incoming shortwave radiation and the albedo. The reference modeled melt is given by $M_{\mathrm{DF}}$ mod

\begin{tabular}{|c|c|c|c|}
\hline & C-DF1 & C-DF2 & C-DF3 \\
\hline Elevation (ma.s.l.) & 3939 & 4554 & 5200 \\
\hline Time frame (days) & 18 & 18 & 18 \\
\hline$M$ meas (m w.e.) & 0.850 & 0.615 & 0.000 \\
\hline$M_{\mathrm{DF}} \bmod (\mathrm{m} w . e)$. & 0.850 & 0.615 & 0.335 \\
\hline$\Delta M_{-0.1^{\circ} \mathrm{C}}$ (m w.e. $)$ & -0.005 & -0.005 & -0.004 \\
\hline$\Delta M_{+0.1^{\circ} \mathrm{C}}(\mathrm{m}$ w.e. $)$ & 0.005 & 0.005 & 0.004 \\
\hline$\Delta M$ ave $\%_{ \pm 0.1{ }^{\circ} \mathrm{C}}$ (m w.e.) & $\pm 0.6 \%$ & $\pm 0.8 \%$ & $\pm 1.2 \%$ \\
\hline$\Delta M_{-1.0^{\circ} \mathrm{C}}(\mathrm{m}$ w.e. $)$ & -0.052 & -0.052 & -0.075 \\
\hline$\Delta M_{+1.0^{\circ} \mathrm{C}}(\mathrm{m}$ w.e. $)$ & 0.052 & 0.052 & 0.066 \\
\hline$\Delta M$ ave $\%_{ \pm 1.0^{\circ} \mathrm{C}}$ (m w.e.) & $\pm 6.1 \%$ & $\pm 8.4 \%$ & $\pm 20.9 \%$ \\
\hline$\Delta M_{-2.5^{\circ} \mathrm{C}}(\mathrm{m}$ w.e. $)$ & -0.130 & -0.130 & -0.138 \\
\hline$\Delta M_{+2.5^{\circ} \mathrm{C}}(\mathrm{m}$ w.e. $)$ & 0.130 & 0.130 & 0.161 \\
\hline$\Delta M$ ave $\%{ }_{ \pm 2.5}{ }^{\circ} \mathrm{C}$ (mw.e.) & $\pm 15.3 \%$ & $\pm 21.1 \%$ & $\pm 44.7 \%$ \\
\hline$\Delta M_{+10 \%}$ sWin $(\mathrm{m}$ w.e. $)$ & 0.025 & 0.025 & 0.020 \\
\hline$\Delta M_{-10 \% \text { sWin }}$ (mw.e.) & -0.025 & -0.025 & -0.020 \\
\hline$\Delta M$ ave $\%{ }_{ \pm 10} \%$ swin (mw.e.) & $\pm 2.9 \%$ & $\pm 4.1 \%$ & $\pm 6.1 \%$ \\
\hline$\Delta M_{+10 \% \text { albedo }}(\mathrm{m}$ w.e. $)$ & -0.035 & -0.036 & -0.029 \\
\hline$\Delta M_{-10 \% \text { albedo }}(\mathrm{m}$ w.e. $)$ & 0.035 & 0.036 & 0.029 \\
\hline$\Delta M$ ave $\% \pm 10 \%$ albedo (m w.e.) & $\pm 4.1 \%$ & $\pm 5.8 \%$ & $\pm 8.7 \%$ \\
\hline
\end{tabular}

In the debris-covered ice melt model we assumed a linear vertical temperature profile within the debris layer $\left(\right.$ with $0^{\circ} \mathrm{C}$ at the melting ice surface), which is usually considered a good approximation for calculating daily melt rates (Mattson and others, 1993; Mayer and others, 2010). In the period under study, refreezing during the night can be considered negligible in the debris-covered areas, because hourly air temperatures at Urdukas were always positive. This is also in agreement with data collected on the tongue of Hinarche glacier, Bagrot valley, CKNP, at 2757 m a.s.l. from 26 July to 5 August 2008 (Mayer and others, 2010), where air temperature ( $2 \mathrm{~m}$ above the debris surface) ranged between $+14^{\circ} \mathrm{C}$ and $+24^{\circ} \mathrm{C}$, and never dropped below $+9.9^{\circ} \mathrm{C}$. When our model is applied to the onset and the end of the ablation season, it may overestimate meltwater discharge, and therefore may require further calibration.

We performed several sensitivity tests and evaluated model responses to varying input data at field survey sites (Tables 4 and 5) as well as over the whole CKNP ablation area (Table 6). First, we considered the debris-covered areas. We varied the daily incoming solar radiation by $\pm 10 \%$ and $\pm 20 \%$. Then we studied the effect of varying the debris thickness upon melt results $( \pm 10 \%, \pm 1 \mathrm{~cm}, \pm 5 \mathrm{~cm}$ and $\pm 10 \mathrm{~cm}$ with respect to the actual debris thickness values). The model response at field survey points (C-DC1 to C-DC4) is shown in Table 4.

These tests suggest that changing the debris thickness or radiative input noticeably affects the debris-covered ice melt. In particular, this appears more evident in the presence of a thin debris thickness. Indeed, whenever shallow debris layers occur (see C-DC3 compared to C-DC1 in Table 4), even slight input variations entail evident changes in the underlying ice ablation, as the debris insulating effect is weaker.

Next, we considered the debris-free areas. We varied the daily incoming solar radiation by $\pm 10 \%$. Then we shifted 
Table 6. Sensitivity test performed by applying different input data to both the debris-free and debris-covered ice melt models. The model results without input variation are shown in line $2(M)$. We considered the whole CKNP ablation area

\begin{tabular}{|c|c|c|c|c|c|c|}
\hline & $\begin{array}{c}\text { DC } \\
\mathrm{km}^{3} \text { w.e. }\end{array}$ & $\begin{array}{c}\text { DF } \\
\mathrm{km}^{3} \text { w.e. }\end{array}$ & $\begin{array}{l}\text { DC+DF } \\
\mathrm{km}^{3} \text { w.e. }\end{array}$ & $\% \triangle D C$ & $\% \triangle D F$ & $\% \Delta$ total \\
\hline M & 0.22 & 1.74 & 1.96 & - & - & - \\
\hline$M_{\text {all debris-free }}$ & 0.00 & 2.22 & 2.22 & - & - & $+13.0 \%$ \\
\hline$M_{+10 \%}$ albedo & 0.22 & 1.64 & 1.86 & - & $-6.0 \%$ & $-5.3 \%$ \\
\hline$M_{-10 \% \text { albedo }}$ & 0.22 & 1.85 & 2.07 & - & $+6.0 \%$ & $+5.3 \%$ \\
\hline$M_{+10 \%} \mathrm{sWin}$ & 0.24 & 1.81 & 2.06 & $+8.7 \%$ & $+4.2 \%$ & $+4.7 \%$ \\
\hline$M_{-10 \% \text { sWin }}$ & 0.20 & 1.67 & 1.87 & $-8.7 \%$ & $-4.2 \%$ & $-4.7 \%$ \\
\hline$M+1.0^{\circ} \mathrm{C}$ & 0.22 & 1.89 & 2.11 & - & $+8.4 \%$ & $+7.4 \%$ \\
\hline$M_{-1.0^{\circ} \mathrm{C}}$ & 0.22 & 1.59 & 1.82 & - & $-8.4 \%$ & $-7.4 \%$ \\
\hline$M_{+10 \% \mathrm{DT}}$ & 0.21 & 1.74 & 1.95 & $-4.3 \%$ & - & $-0.5 \%$ \\
\hline$M_{-10 \% \mathrm{DT}}$ & 0.23 & 1.74 & 1.97 & $+4.9 \%$ & - & $+0.6 \%$ \\
\hline$M_{+50 \% ~ D T}$ & 0.18 & 1.74 & 1.92 & $-17.3 \%$ & - & $-2.0 \%$ \\
\hline$M_{-50 \% \mathrm{DT}}$ & 0.30 & 1.74 & 2.04 & $+34.2 \%$ & - & $+3.9 \%$ \\
\hline$M_{+100 \% \mathrm{DT}}$ & 0.16 & 1.74 & 1.90 & $-28.1 \%$ & - & $-3.2 \%$ \\
\hline
\end{tabular}

the daily air temperature by $\pm 0.1, \pm 1.0$ and $\pm 2.5^{\circ} \mathrm{C}$ with respect to the measured values. Finally, we investigated the effect of changing the albedo values by $\pm 10 \%$. Table 5 shows the model responses at field survey points (C-DF1 to C-DF3).

The debris-free ice model is very sensitive to variations in air temperature, and the ablation varied by $\pm 45 \%$ with changes of $\pm 2.5^{\circ} \mathrm{C}$. Minor impacts derived from changing $\mathrm{SW}_{\text {in }}$ inputs, showing a maximum variation of only $6 \%$. This is a consequence of applying an enhanced $T$-index model, which indeed gives a primary role to temperature in driving ice melt, and a complementary role to incoming solar radiation (see, e.g., Pellicciotti and others, 2005). Concerning ice albedo, our model assumes a constant value of 0.30 for the whole area, thus probably entailing an over- or underestimation of the actual ice melt. Common albedo values for snow and ice surfaces range from 0.20 to 0.85 ; the albedo therefore has a very large and important influence on the total shortwave radiation absorbed by the surface, $\mathrm{SW}_{\text {in }} \cdot(1-\alpha)$, and hence on ablation. In the absence of direct measurements, albedo is often estimated from 'typical' published values for snow or ice (Cutler and Munro, 1996): a clean ice surface generally features an albedo of $0.30-0.46$, while a debris-rich ice surface is characterized by an albedo of $0.06-0.30$ (Cuffey and Paterson, 2010). Thus, the choice of albedo is a very critical issue in accurately estimating the ice melt. In this study, we adopted the mean value (i.e. 0.30) obtained by incoming and outgoing solar radiation data gathered by the supraglacial AWS placed at Concordia (in a debris-free area of Baltoro glacier). In previous studies, some authors applied similar approaches using an albedo of 0.30 (e.g. Pellicciotti and others, 2005). Oerlemans (2001) reported a mean albedo value for debris-free ice of $\sim 0.30$. So we followed these previous studies supporting the use of a constant albedo of 0.30 . The sensitivity test at field survey sites showed that changing the albedo by $\pm 10 \%$ may lead to melt change of up to $\pm 9 \%$ on debris-free areas (Table 5 ).

In addition to these model sensitivity tests, we considered the whole CKNP area totally debris-free, obtaining a total melt of $2.22 \mathrm{~km}^{3}$ w.e., with an increase of $0.48 \mathrm{~km}^{3}$ w.e. (more than twice as much) with respect to that obtained on actual debris-free areas (Table 6). This suggests that the debris layer is thick enough (more than the local critical value; Mattson and others, 1993) to constrain the ice melt rates on average. To assess the effects of albedo, we changed the albedo of debris-free areas by a factor of $\pm 10 \%$, finding only a moderate impact on total melt $( \pm 5 \%)$. Similar results were obtained by changing $\mathrm{SW}_{\text {in }}$ by $\pm 10 \%$. Moreover, stronger impacts $( \pm 7 \%)$ are caused by changing air temperature by $\pm 1.0^{\circ} \mathrm{C}$. Finally, we investigated the impact of DT by changing its values by $\pm 10 \%, \pm 50 \%$ and $+100 \%$. In spite of the small impact on the total melt amount $(+3.9 \%$ with $-50 \%$ of DT and $-3.2 \%$ with $+100 \%$ of DT), the applied changes largely affected debris-covered ice melt. As the overall mean DT we derived from Landsat imagery $(0.23 \mathrm{~m})$ is surely higher than the local critical value ( $\sim 0.05 \mathrm{~m}$ on Baltoro glacier according to Mihalcea and others, 2006), the model is more sensitive to reduction than to increases of the actual DT value. This agrees with the well-known nonlinear relation between debris-covered ice melt and DT (see also fig. 7 in Mihalcea and others, 2006). Indeed, when DT was decreased by $50 \%$, melt in debriscovered areas increased by up to $+34 \%$, while when it was doubled, melt decreased by $-28 \%$ (see Table 6 ).

\section{CONCLUSIONS}

We applied a simple model to evaluate the meltwater from debris-free and debris-covered ice ablation in the CKNP area, a wide glacierized zone of Pakistan. Our model estimates melt below $5200 \mathrm{~m}$ a.s.l. by applying an enhanced $T$-index model over the debris-free areas, and computing the conductive heat flux through the debris layer on the debriscovered zones. We neglected snowmelt, since snow data in the study area are not systematically available. We then focused on the peak ablation season, from 23 July to 9 August 2011, when meltwater is largely derived from ice melt, with snow thaw playing a minor role (Soncini and others, 2015). Glacier features (i.e. surface area, supraglacial debris occurrence and thickness) were estimated from remote-sensing analysis of recent satellite imagery (201011). Meteorological input data were distributed starting from data acquired at Askole. The data distribution procedure was validated by comparing the results with data recorded by two AWSs within the SHARE network (Urdukas and 
Concordia). The modeled ablation data were in strong agreement with measurements collected in the field during 2011 on Baltoro glacier, which can be considered representative of CKNP glaciers.

Our model estimated $0.223 \mathrm{~km}^{3}$ (on average, $0.012 \mathrm{~km}^{3} \mathrm{~d}^{-1}$; min-max $0.006-0.016 \mathrm{~km}^{3} \mathrm{~d}^{-1}$ ) of meltwater from the debris-covered parts, and $1.740 \mathrm{~km}^{3}$ (on average, $0.097 \mathrm{~km}^{3} \mathrm{~d}^{-1}$; min-max $0.041-0.139 \mathrm{~km}^{3} \mathrm{~d}^{-1}$ ) from debrisfree sectors of the CKNP glacier ablation zone from 23 July to 9 August 2011. The total fresh water from the ablation areas of CKNP glaciers during the same period was therefore $1.963 \mathrm{~km}^{3}$ (on average, $0.109 \mathrm{~km}^{3} \mathrm{~d}^{-1}$ ), corresponding, for example, to $14 \%$ of the water contained in a large strategic dam along the Indus River, of which all CKNP glaciers are tributaries.

The present model requires only a small number of input data, such as air temperature and $\mathrm{SW}_{\text {in }}$ (recorded by most of the standard AWSs), a DEM, and debris thickness measurements collected in the field. The relatively simple models we developed should provide portability to other regions, even if adjustments of the parameters against field measurements are necessary. In particular, (1) the lapse rate to distribute the air temperature (see Eqn (2)) should be locally evaluated; (2) the use of a constant albedo of 0.30 might be invalid for areas with debris-free ice affected by dust and black carbon deposition (see Azzoni and others, 2014), thus requiring dedicated analyses; (3) the debris effective thermal resistance (DR) estimation requires debris-covered ice ablation and debris surface temperature data collected in the field.

The sensitivity tests suggest that melting will increase largely if summer air temperature increases. Also, any increase in the extent of debris coverage (which will likely occur due to augmented macrogelivation processes and rockfall events) will affect melt depending on new debris thickness. Thus, it will be important to monitor debris cover variations in time to update these crucial input data. Finally, albedo variations have to be properly considered, because surface darkening is reported as a result of increasing amounts of fine debris (Oerlemans and others, 2009; Azzoni and others, 2014). A further improvement of our approach will be the spatial distribution of debris-free ice albedo by applying methods based on remote-sensing investigations (see Klok and others, 2003).

\section{ACKNOWLEDGEMENTS}

We thank the Associate Editor Shin Sugiyama and three anonymous reviewers for their help in improving the first draft of this paper and for useful comments and suggestions. Landsat data used in this paper are distributed by the Land Processes Distributed Active Archive Center (LP DAAC), located at the US Geological Survey (USGS) National Center for Earth Resources Observation and Science (EROS), Sioux Falls, SD. This research was carried out under the umbrella of the SEED and SHARE-PAPRIKA projects. SEED is a project funded by the Pakistani and Italian governments, and managed by the Ev-K2-CNR Association. SHAREPAPRIKA is a project funded and managed by the EV-K2CNR Association (it is the twin project of the PAPRIKA France program). The CKNP glacier inventory used in this study is part of the SHARE GEO Network and data are available upon request to the Ev-K2-CNR headquarters (http://geonetwork.evk2cnr.org). The Askole, Urdukas and Concordia AWSs belong to a meteorological network in the
CKNP area serving the SHARE program and were developed and are managed by Ev-K2-CNR. We acknowledge the Pakistan Meteorological Department (PMD) for support and cooperation. The data analysis was performed in the framework of the PRIN project 2010/11 (2010AYKTAB_ 006). We thank Carol Rathman for checking and improving the English language of the manuscript.

\section{REFERENCES}

Archer DR (2003) Contrasting hydrological regimes in the Indus Basin. J. Hydrol., 274, 198-210 (doi: 10.1016/S0022-1694(02) 00414-6)

Azzoni RS, Senese A, Zerboni A, Maugeri M, Smiraglia C and Diolaiuti G (2014) A novel integrated method to describe dust and fine supraglacial debris and their effects on ice albedo: the case study of Forni Glacier, Italian Alps. Cryosphere Discuss., 8, 3171-3206 (doi: 10.5194/tcd-8-3171-2014)

Barrand N and Murray T (2006) Multivariate controls on the incidence of glacier surging in the Karakoram Himalaya. Arct. Antarct. Alp. Res., 38, 489-498 (doi: 10.1657/1523-0430(2006) 38\%5B489:MCOTIO\%5D2.0.CO;2)

Barsi JA, Barker JL and Schott JR (2003) An atmospheric correction parameter calculator for a single thermal band earth-sensing instrument. In Stein T ed. IGARSS 2003, International Geoscience and Remote Sensing Symposium, 21-25 July 2003, Toulouse, France. Proceedings. Institute of Electrical and Electronic Engineers, Piscataway, NJ (doi: 10.1109/IGARSS.2003.1294665)

Barsi JA, Schott JR, Palluconi FD and Hook SJ (2005) Validation of a web-based atmospheric correction tool for single thermal band instruments. Proc. SPIE-Int. Soc. Opt. Eng., 5882 (doi: 10.1117/ 12.619990)

Bhambri R and Bolch T (2009) Glacier mapping: a review with special reference to the Indian Himalayas. Progr. Phys. Geog., 33, 672-704 (doi: 10.1177/0309133309348112)

Bocchiola D and Diolaiuti G (2013) Recent (1980-2009) evidence of climate change in the upper Karakoram, Pakistan. Theor. Appl. Climatol., 111 (doi: 10.1007/s00704-012-0803-y)

Bocchiola D and 8 others (2011) Prediction of future hydrological regimes in poorly gauged high altitude basins: the case study of the upper Indus, Pakistan. Hydrol. Earth Syst. Sci., 15, 2059-2075 (doi: 10.5194/hess-15-2059-2011)

Bolch T and 11 others (2012) The state and fate of Himalayan glaciers. Science, 336, 310-314 (doi: 10.1126/science.1215828)

Brown DG, Lusch DP and Duda KA (1998) Supervised classification of types of glaciated landscapes using digital elevation data. Geomorphology, 21, 233-250 (doi: 10.1016/S0169-555X (97)00063-9)

Coll C, Galve JM, Sánchez JM and Caselles V (2010) Validation of Landsat-7/ETM+ thermal-band calibration and atmospheric correction with ground-based measurements. IEEE Trans. Geosci. Remote Sens., 48(1), 547-555 (doi: 10.1109/ TGRS.2009.2024934)

Conway WM (1894) Climbing and exploration in the Himalayas. Fisher Unwin, London

Copland L and 7 others (2011) Expanded and recently increased glacier surging in the Karakoram. Arct. Antarct. Alp. Res., 43, 503-516 (doi: 10.1657/1938-4246-43.4.503)

Cuffey KM and Paterson WSB (2010) The physics of glaciers, 4th edn. Academic Press, Amsterdam

Cutler PM and Munro DS (1996) Visible and near-infrared reflectivity during the ablation period on Peyto Glacier, Alberta, Canada. J. Glaciol., 42(141), 333-340

De Filippi F (1912) La spedizione di S.A.R il Principe Luigi Amedeo di Savoia Duca degli Abruzzi nel Karakorum e nell'Himalaya occidentale (1909). Zanichelli, Bologna

Desio A, Marussi A and Caputo M (1961) Glaciological research of the Italian Karakorum Expedition 1953-1955. IAHS Publ. 52 (General Assembly of Helsinki 1960 - Snow and Ice), 224-232 
Diolaiuti G, Pecci M and Smiraglia C (2003) Liligo Glacier (Karakoram): reconstruction of the recent history of a surgetype glacier. Ann. Glaciol., 36, 168-172 (doi: 10.3189/ 172756403781816103)

Foster LA, Brock BW, Cutler MEJ and Diotri F (2012) A physically based method for estimating supraglacial debris thickness from thermal band remote-sensing data. J. Glaciol., 58(210), 677-691 (doi: 10.3189/2012JoG11J194)

Fowler HJ and Archer DR (2006) Conflicting signals of climatic change in the upper Indus basin. J. Climate, 19, 4276-4293 (doi: 10.1175/JCLI3860.1)

Fujita K and Sakai A (2014) Modelling runoff from a Himalayan debris-covered glacier. Hydrol. Earth Syst. Sci., 18(7), 2679-2694 (doi: 10.5194/hess-18-2679-2014 014)

Fyffe C and 6 others (2014) A distributed energy-balance melt model of an alpine debris-covered glacier. J. Glaciol., 60(221), 587-602 (doi: 10.3189/2014JoG13J148)

Gardelle J, Berthier E and Arnaud Y (2012) Slight mass gain of Karakoram glaciers in the early 21 st century. Nature Geosci., 5, 322-325, (doi: 10.1038/ngeo1450 (doi: 10.1038/ngeo1450)

Gardelle J, Berthier E, Arnaud Y and Kääb A (2013) Region-wide glacier mass balances over the Pamir-Karakoram-Himalaya during 1999-2011. Cryosphere, 7, 1263-1286 (doi: 10.5194/tc7-1263-2013)

Gardner AS and 15 others (2013) A reconciled estimate of glacier contributions to sea level rise: 2003 to 2009. Science, 340, 852-857 (doi: 10.1126/science.1234532)

Han H, Ding Y and Liu S (2006) A simple model to estimate ice ablation under a thick debris layer. J. Glaciol., 52(179), 528-536 (doi: 10.3189/172756506781828395)

Hewitt K (2005) The Karakoram Anomaly? Glacier expansion and the 'elevation effect', Karakoram Himalaya. Mt. Res. Dev., 25, 332-340 (doi: 10.1659/0276-4741(2005)025\%5B0332:TKAGEA\%5D2.0.CO;2)

Hewitt K (2007) Tributary glacier surges: an exceptional concentration at Panmah Glacier, Karakoram, Himalaya. J. Glaciol., 53, 181-188 (doi: 10.3189/172756507782202829)

Hewitt K (2011) Glacier change, concentration, and elevation effects in the Karakoram Himalaya, upper Indus basin. Mt. Res. Dev., 31, 188-200 (doi: 10.1659/MRD-JOURNAL-D-1100020.1)

Hewitt K, Wake CP, Young GJ and David C (1989) Hydrological investigations at Biafo Glacier, Karakorum Range, Himalaya; an important source of water for the Indus River. Ann. Glaciol., 13, 103-108

Hock R (1999) A distributed temperature-index ice- and snowmelt model including potential direct solar radiation. J. Glaciol., 45(149), 101-111

International Centre for Integrated Mountain Development (IClMOD) (2013) State of the knowledge and Workshop on Hindu Kush Himalayan Cryosphere Data Sharing Policy. International Conference on the Cryosphere of the Hindu Kush Himalayas, 14-18 May 2012. (ICIMOD Project Document) ICIMOD, Kathmandu

Kääb A, Berthier E, Nuth C, Gardelle J and Arnaud Y (2012) Contrasting patterns of early twenty-first-century glacier mass change in the Himalayas. Nature, 488, 495-498 (doi: 10.1038/ nature11324)

Kayastha RB, Takeuchi Y, Nakawo M and Ageta Y (2000) Practical prediction of ice melting beneath various thickness of debris cover on Khumbu Glacier, Nepal using a positive degree day factor. IAHS Publ. 264 (Symposium at Seattle 2000 - DebrisCovered Glaciers), 71-81

Klok EJ, Greuell W and Oerlemans J (2003) Temporal and spatial variation of the surface albedo of Morteratschgletscher, Switzerland, as derived from 12 Landsat images. J. Glaciol., 49(167), 491-502 (doi: 10.3189/172756503781830395)

Kotlyakov V, Osipova G and Tsvetkov D (2008) Monitoring surging glaciers of the Pamirs, central Asia, from space. Ann. Claciol., 48, 125-134 (doi: 10.3189/172756408784700608)
Lejeune Y, Bertrand JM, Wagnon P and Morin S (2013) A physically based model for the year-round surface energy and mass balance of debris-covered glaciers. J. Glaciol., 59(214), 327-344 (doi: 10.3189/2013JoG12J149)

Mattson LE and Gardner JS (1989) Energy exchange and ablation rates on the debris-covered Rakhiot Glacier, Pakistan. Z. Gletscherkd. Glazialgeol., 25(1), 17-32

Mattson LE, Gardner JS and Young GJ (1993) Ablation on debris covered glaciers: an example from the Rakhiot Glacier, Punjab, Himalaya. IAHS Publ. 218 (Symposium at Kathmandu $1992-$ Snow and Glacier Hydrology), 289-296

Mayer C, Lambrecht A, Beló M, Smiraglia C and Diolaiuti G (2006) Glaciological characteristics of the ablation zone of Baltoro glacier, Karakoram, Pakistan. Ann. Glaciol., 43, 123-131 (doi: 10.3189/172756406781812087)

Mayer C and 6 others (2010) Analysis of glacial meltwater in Bagrot Valley, Karakoram. Mt. Res. Dev., 30(2), 169-177 (doi: 10.1659/MRD-JOURNAL-D-09-00043.1)

Mihalcea C, Mayer C, Diolaiuti G, Lambrecht A, Smiraglia C and Tartari G (2006) Ice ablation and meteorological conditions on the debris-covered area of Baltoro glacier, Karakoram, Pakistan. Ann. Glaciol., 43, 292-300 (doi: 10.3189/ 172756406781812104)

Mihalcea C and 7 others (2008a) Spatial distribution of debris thickness and melting from remote-sensing and meteorological data, at debris-covered Baltoro glacier, Karakoram, Pakistan. Ann. Glaciol., 48, 49-57 (doi: 10.3189/172756408784700680)

Mihalcea C and 7 others (2008b) Using ASTER satellite and groundbased surface temperature measurements to derive supraglacial debris cover and thickness patterns on Miage Glacier (Mont Blanc Massif, Italy). Cold Reg. Sci. Technol., 52, 341-354 (doi: 10.1016/j.coldregions.2007.03.004)

Minora U and 11 others (2013) 2001-2010 glacier changes in the Central Karakoram National Park: a contribution to evaluate the magnitude and rate of the 'Karakoram anomaly'. Cryosphere Discuss., 7, 2891-2941 (doi: 10.5194/tcd-7-2891-2013)

Nakawo M and Rana B (1999) Estimate of ablation rate of glacier ice under a supraglacial debris layer. Geogr. Ann., 81A(4), 695-701

Nakawo M and Takahashi S (1982) A simplified model for estimating glacier ablation under a debris layer. IAHS Publ. 138 (Symposium at Exeter 1982 - Hydrological Aspects of Alpine and High Mountain Areas), 137-145 (doi: 10.3189/ 172756481794352432)

Nakawo M and Young GJ (1981) Field experiments to determine the effect of a debris layer on ablation of glacier ice. Ann. Glaciol., 2, 85-91

Nakawo M, Moroboshi T and Uehara S (1993) Satellite data utilization for estimating ablation of debris covered glaciers. IAHS Publ. 218 (Symposium at Kathmandu 1992 - Snow and Glacier Hydrology), 75-83

Nakawo M, Raymond CF and Fountain A eds (2000). IAHS Publ. 264 (Workshop at Seattle 2000 - Debris-Covered Glaciers)

NASA ed. (2011) Landsat 7 science data users handbook. Landsat Project Science Office, NASA Goddard Space Flight Center, Greenbelt, MD

Nicholson L and Benn DI (2006) Calculating ice melt beneath a debris layer using meteorological data. J. Glaciol., 52(178), 463-470 (doi: 10.3189/172756506781828584)

Oerlemans J (2001) Glaciers and climate change. Balkema, Lisse

Oerlemans J, Giesen RH and Van den Broeke MR (2009) Retreating alpine glaciers: increased melt rates due to accumulation of dust (Vadret da Morteratsch, Switzerland). J. Glaciol., 55, 729-736 (doi: 10.3189/002214309789470969)

Peel MC, Finlayson BL and McMahon TA (2007) Updated world map of the Köppen-Geiger climate classification. Hydrol. Earth Syst. Sci., 11, 1633-1644 (doi: 10.5194/hess-11-1633-2007)

Pellicciotti F, Brock BW, Strasser U, Burlando P, Funk M and Corripio JG (2005) An enhanced temperature-index glacier melt model including shortwave radiation balance: development and 
testing for Haut Glacier d'Arolla, Switzerland. J. Glaciol., 51, 573-587 (doi: 10.3189/172756505781829124)

Quincey DJ, Braun M, Bishop MP, Hewitt K and Luckman A (2011) Karakoram glacier surge dynamics. Geophys. Res. Lett., 38, L18504 (doi: 10.1029/2011GL049004)

Raina VK and Srivastava D (2008) Glacier atlas of India. Geological Society of India, Bangalore

Rana B, Nakawo M, Fukushima Y and Ageta Y (1997) Application of a conceptual precipitation-runoff model (HYCYMODEL) in a debris-covered glacierized basin in the Langtang Valley, Nepal Himalaya. Ann. Glaciol., 25, 226-231

Reid TD and Brock BW (2010) An energy-balance model for debris-covered glaciers including heat conduction through the debris layer. J. Glaciol., 56(199), 903-916 (doi: 10.3189/ 002214310794457218)

Richards JA (1999) Remote sensing digital image analysis. SpringerVerlag, Berlin (doi: 10.1007/978-3-662-03978-6)

Shekhar MS, Chand H, Kumar S, Srinivasan K and Ganju A (2010) Climate-change studies in the western Himalaya. Ann. Glaciol., 51, 105-112 (doi: 10.3189/172756410791386508)

Soncini A and 9 others (2015) Future hydrological regimes in the upper Indus basin: a case study from a high altitude glacierized catchment. J. Hydrometeorol. (doi: 10.1175/JHM-D-14-0043.1)

Takeuchi N, Kohshima S, Yoshimura Y, Seko K and Fujita K (2000) Characteristics of cryoconite holes on a Himalayan glacier, Yala Glacier, central Nepal. Bull. Glaciol. Res. 17, 51-59
Taschner S and Ranzi R (2002) Comparing the opportunities of LANDSAT-TM and ASTER data for monitoring a debris covered glacier in the Italian Alps within GLIMS Project. In IGARSS 2002, International Geoscience and Remote Sensing Symposium, 24-28 June 2002, Toronto, Canada. Proceedings, Vol. 2. Institute of Electrical and Electronic Engineers, Piscataway, NJ, 1044-1046 (doi: 10.1109/IGARSS.2002.1025770)

Thompson MH (1974) Some construction aspects of Tarbela Dam, J. Construc. Div., 100(3), 247-255

Winiger M, Gumpert M and Yamout H. 2005. KarakorumHindukush-Western Himalaya: assessing high-altitude water resources. Hydrol. Process., 19(12), 2329-2338 (doi: 10.1002/ hyp.5887)

Young GJ and Hewitt K (1993) Glaciohydrological features of the Karakoram Himalaya: measurement possibilities and constraints. IAHS Publ. 218 (Symposium at Kathmandu 1992 Snow and Glacier Hydrology), 273-283

Zhang Y, Fujita K, Liu SY, Liu Q and Nuimura T (2011) Distribution of debris thickness and its effect on ice melt at Hailuogou glacier, southeastern Tibetan Plateau, using in situ surveys and ASTER imagery. J. Glaciol., 57(206), 1147-1157 (doi: 10.3189/ 002214311798843331)

Zhang Y, Hirabayashi Y, Fujita K, Liu S and Liu Q (2013) Spatial debris-cover effect on the maritime glaciers of Mount Gongga, south-eastern Tibetan Plateau. Cryosphere Discuss., 7, 2413-2453 (doi: 10.5194/tcd-7-2413-2013) 